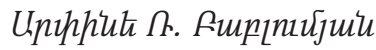
uщunर्umlumu qhunnıpjniuutiph ptliumonı

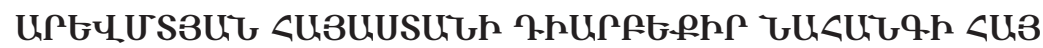

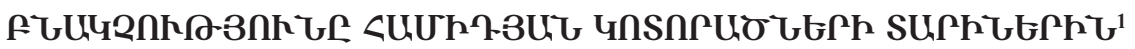

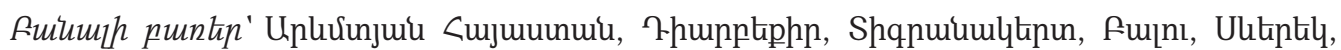

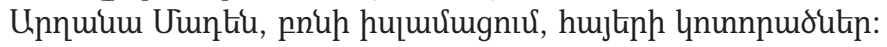

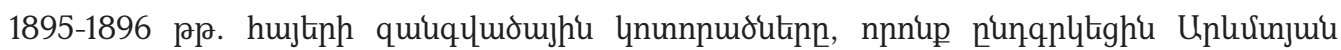

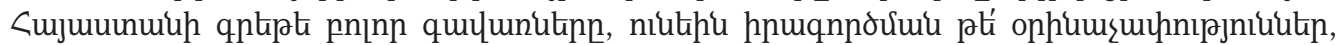

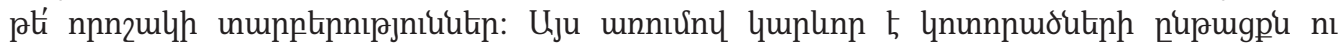

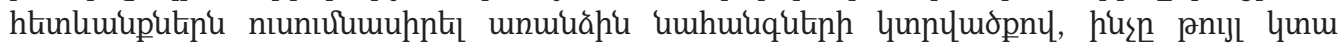

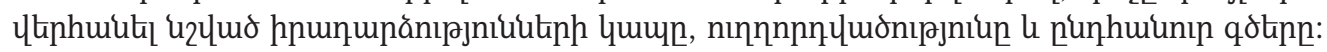

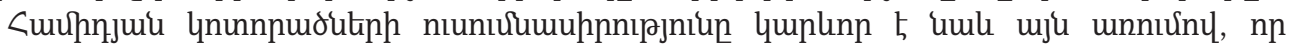

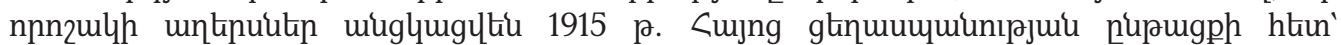

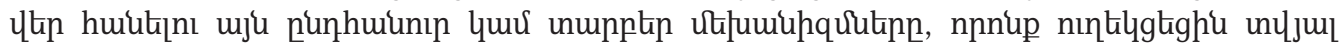

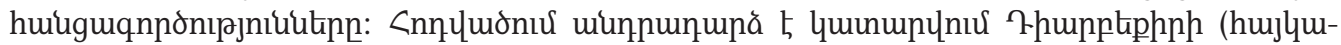

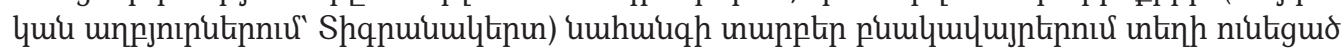

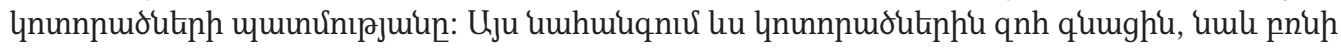

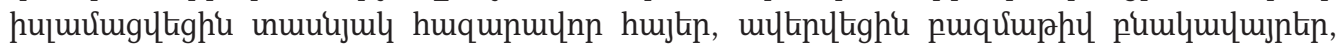

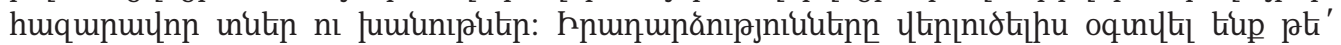

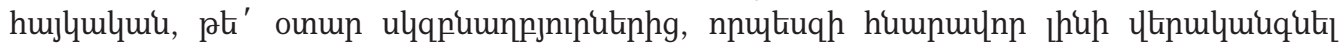

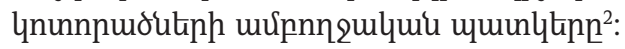

$* * * *$

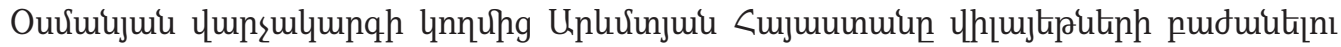

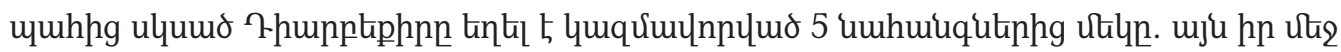

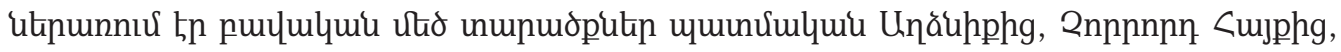

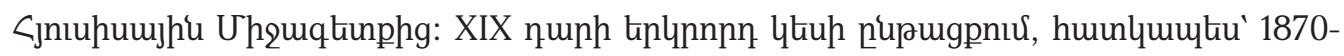

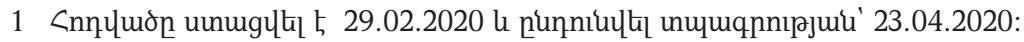

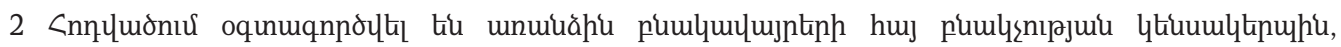

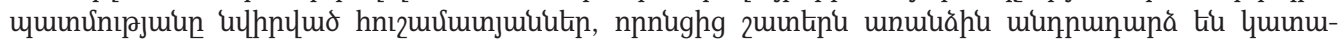

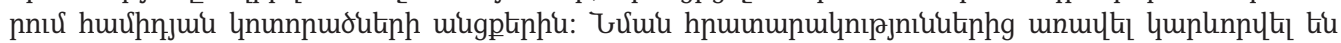

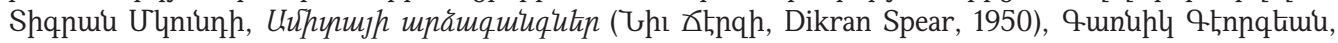

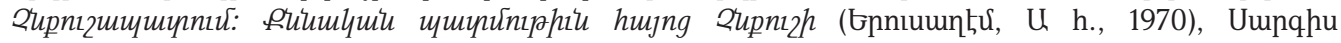

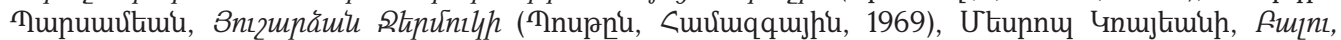

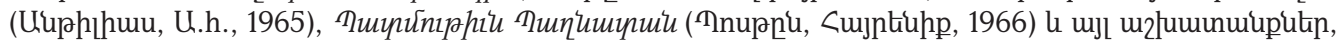

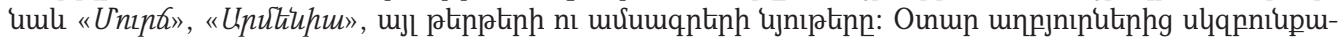

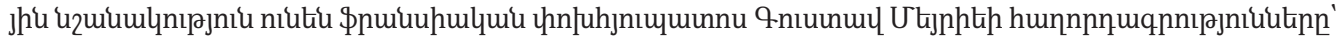
"Армянскій вопросъ по документамъ франиузской Желтой Книги," в Братская Помощь пострадавшимъ в Туриии Армянамъ, отделъ II (Москва, 1898), uwh quplnnцㄴ tú htunljul шгlumumuuputinn' Rev. Edward Bliss, Turkey and the Armenian Atrocities (Fresno: Mesag Publishing, 1982); Rev. George Filian, Armenia and Her People or the Story of Armenia by an Armenian (Hartford, Conn., American publishing company, 1896); Rendel Harris and Helen Harris, Letters from the Scenes of Recent Massacres in Armenia (London: James Nisbet \& Co., 1897), uJı hnuunupulynıpjnıuutip: 


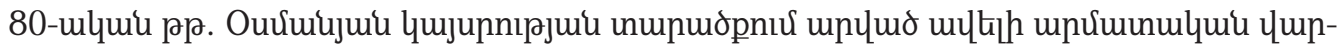

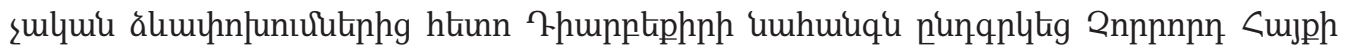

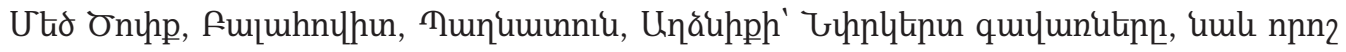

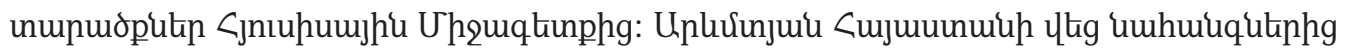

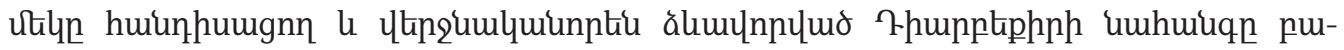

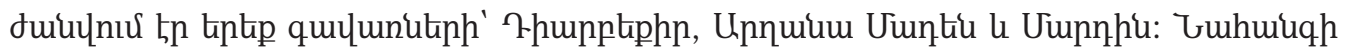

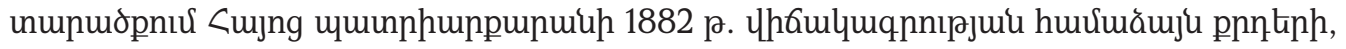

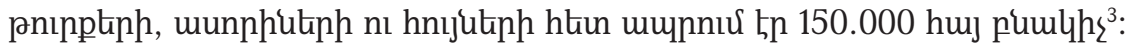

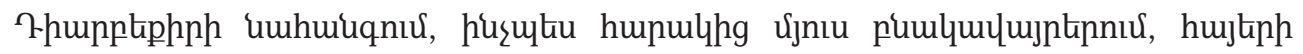

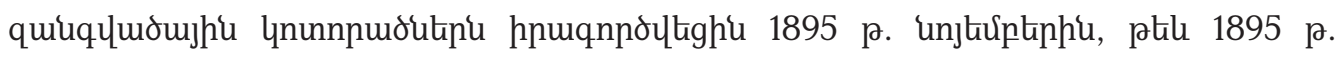

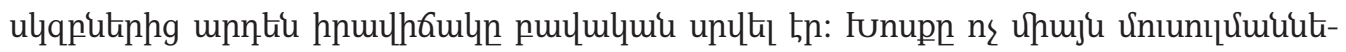

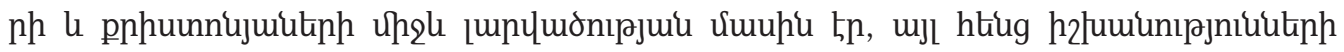

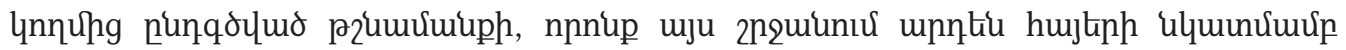

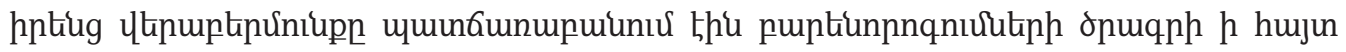

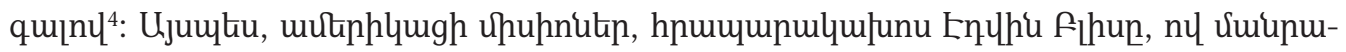

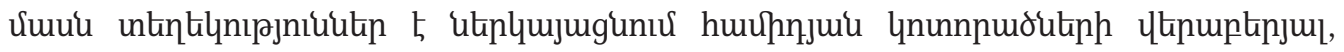

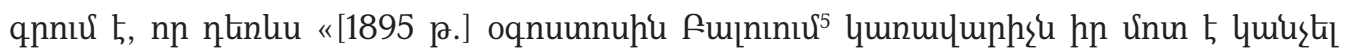

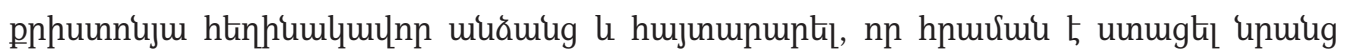

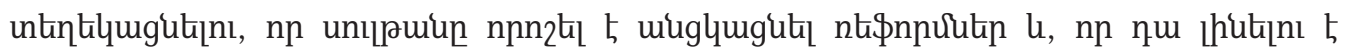

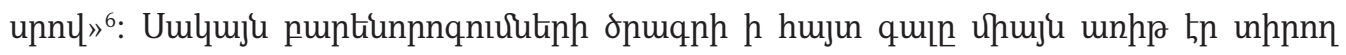

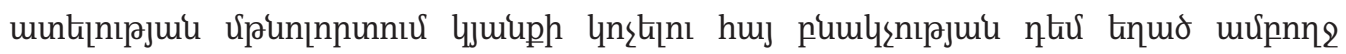

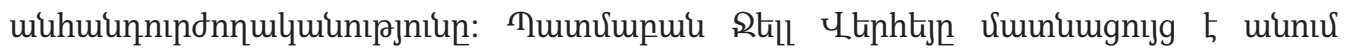

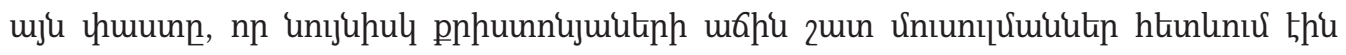

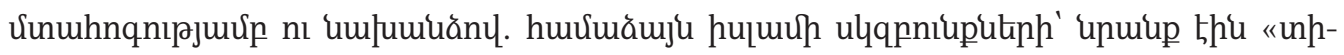

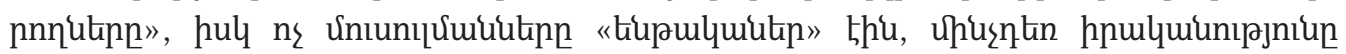

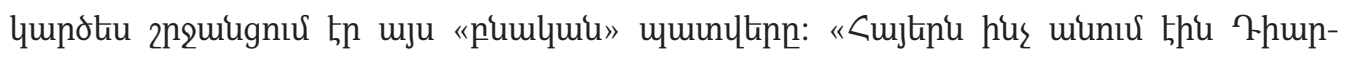

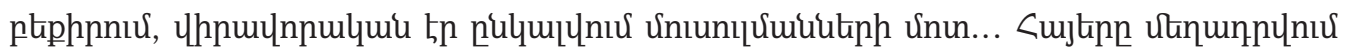

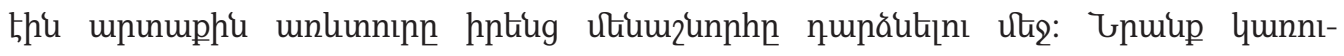

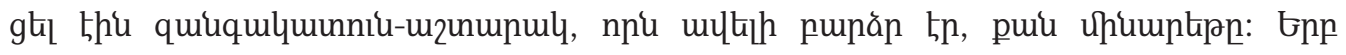

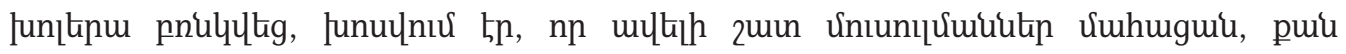

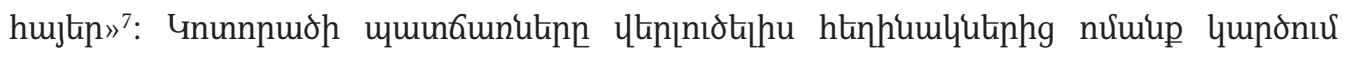

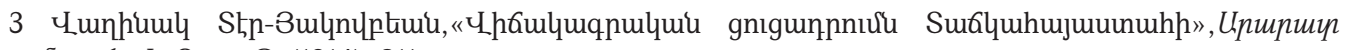

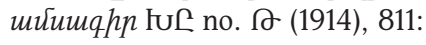

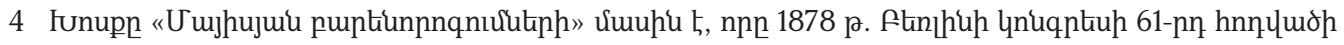

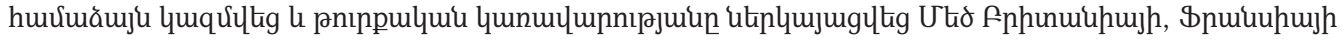

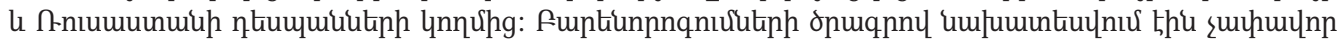

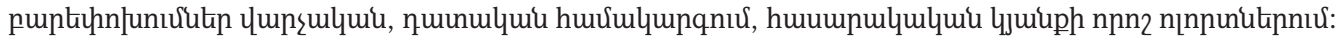

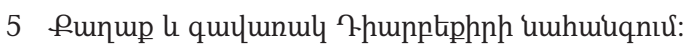

6 Bliss, Turkey and the Armenian Atrocities, 484.

7 Jelle Verheij, "Diarbekir and the Armenian crisis of 1895," in Social Relations in Ottoman Diyarbekir: 1870-1915, ed. Joost Jongarden and Jelle Verheij (Leiden, Boston: Brill, 2012), 91. 


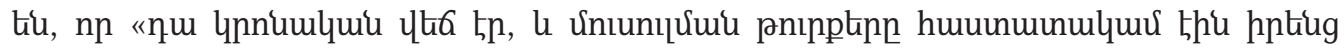

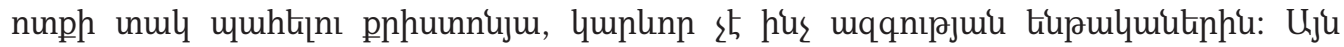

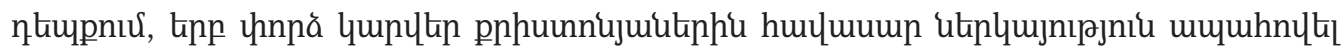

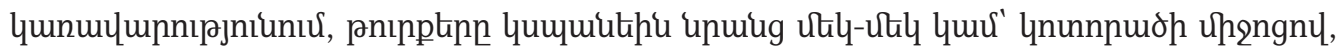

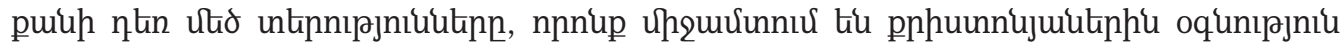

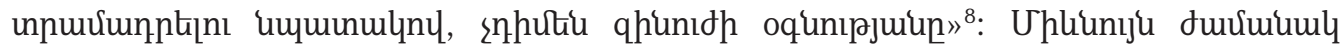

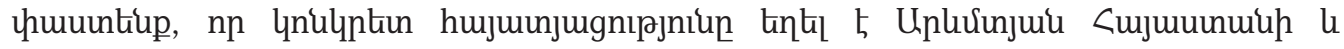

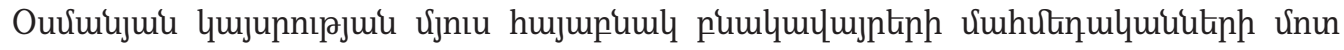

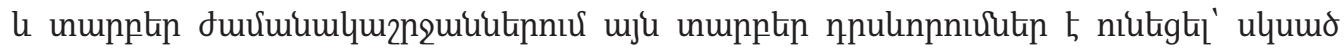

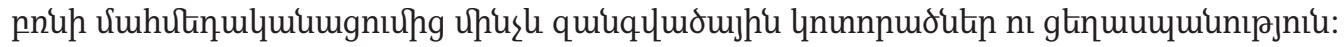

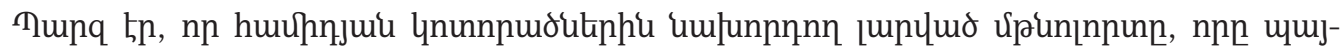

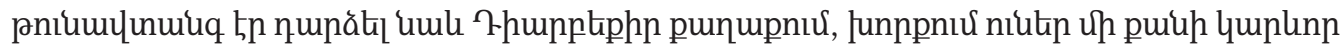

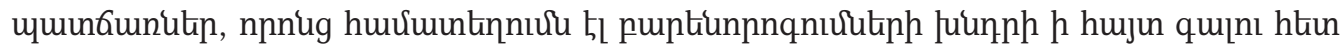
huiqukgnhu quiuqumoujhu lnunnnuơtinh:

\section{5 ஓ. Ynunnpuдp R-pupptphp punupnıu}

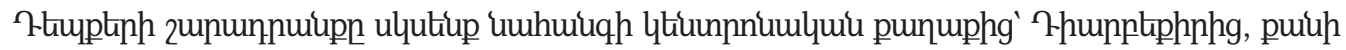

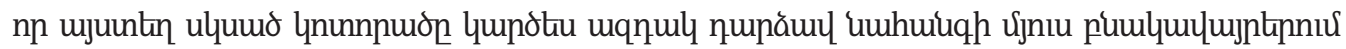

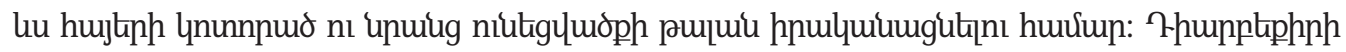

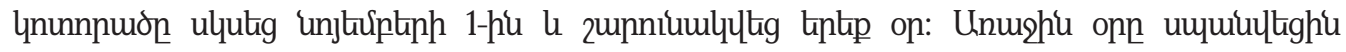

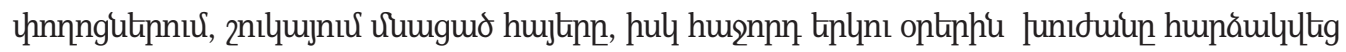

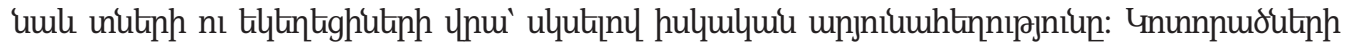

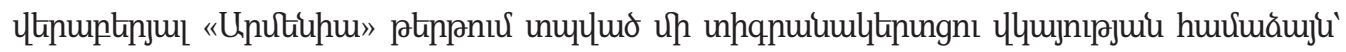

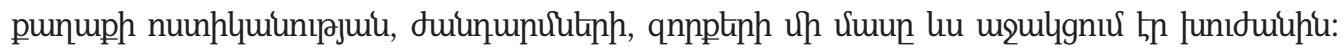

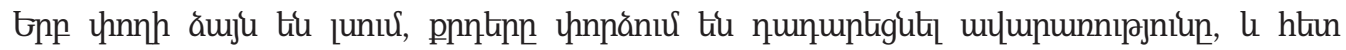

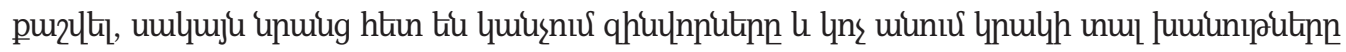

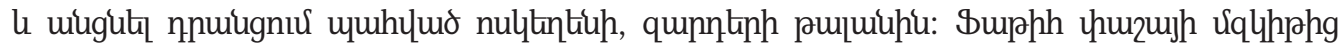

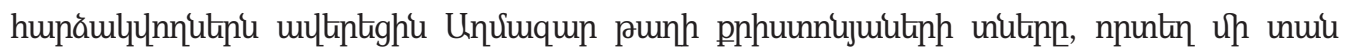

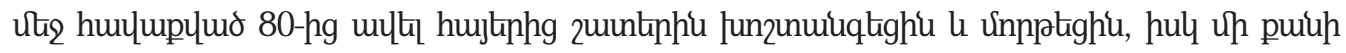

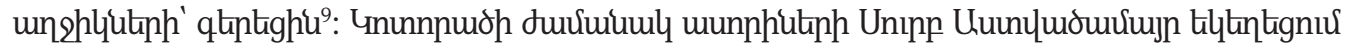

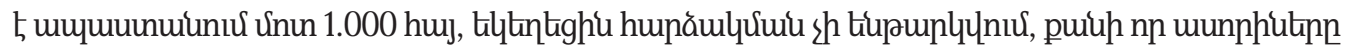

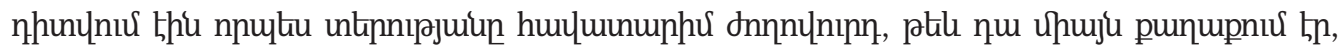

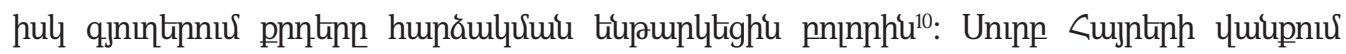

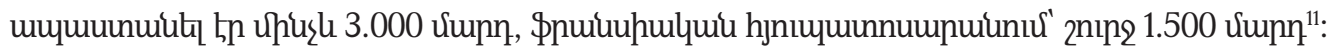

8 Allen Tupper, Around the World with Eyes Wide Open. The Wonders of the World Pictured by Pen and Pencil (New York, 1898), 420.

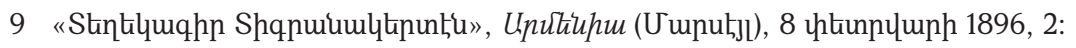

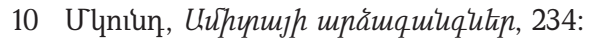

11 “Армянскій вопросъ," 110. 


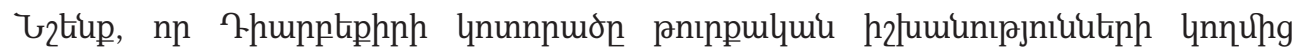

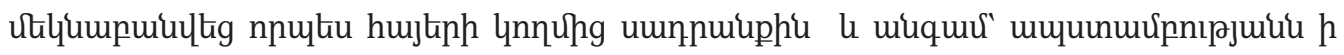

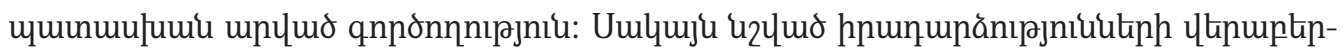

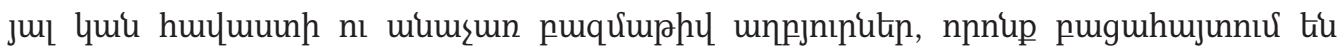

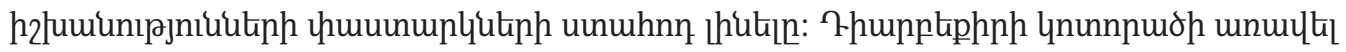

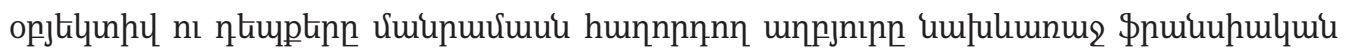

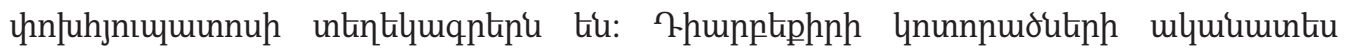

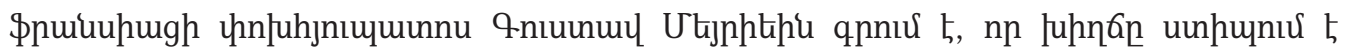

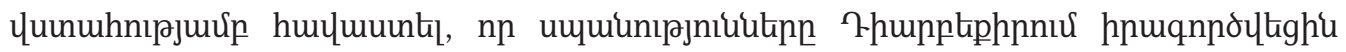

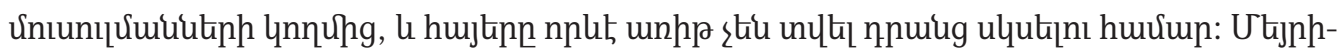

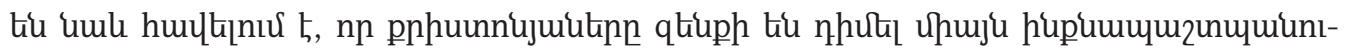

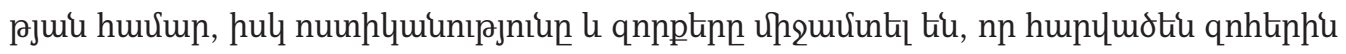

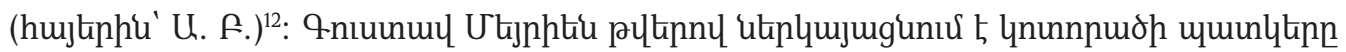

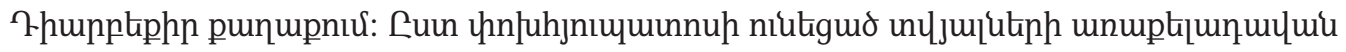

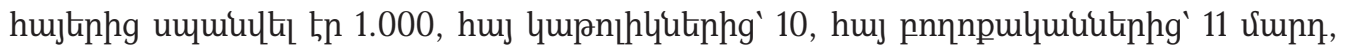

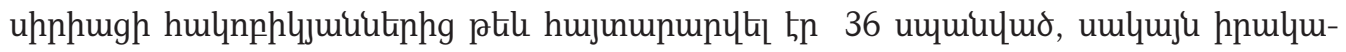

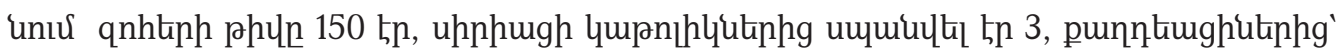

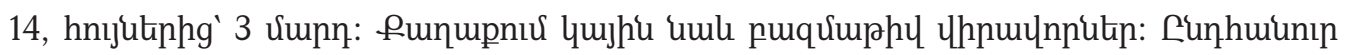

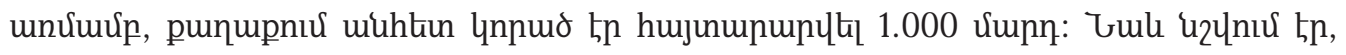

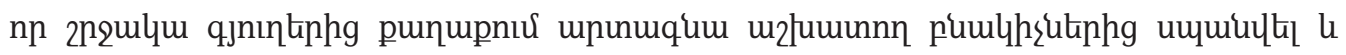

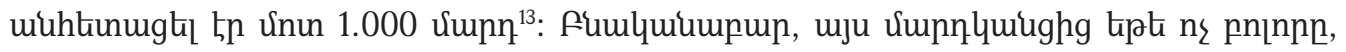

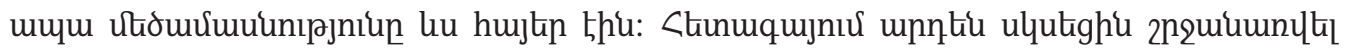

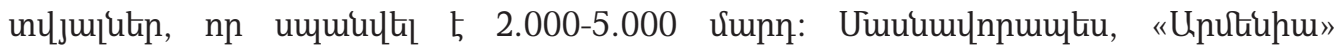

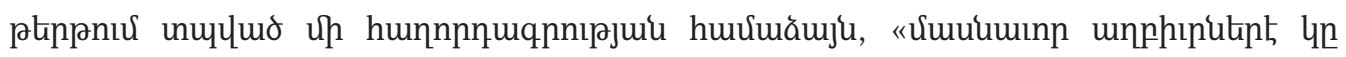

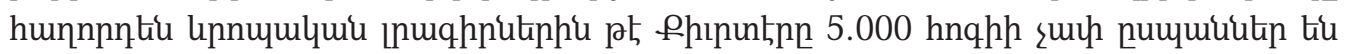

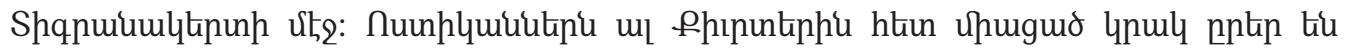

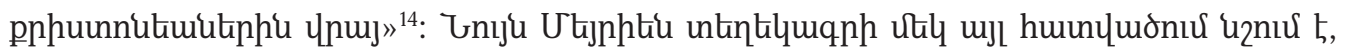

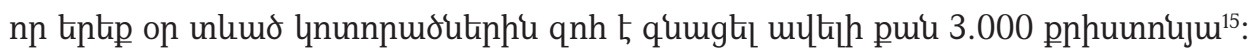

\section{5 р. Ynunnpudutipp Thupptppph uwhuiqh unupptp pumluuluyptipniv}

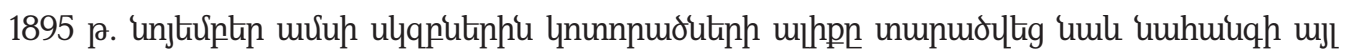

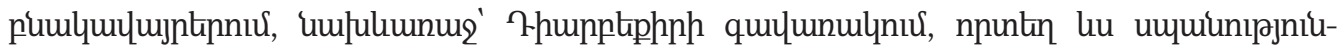

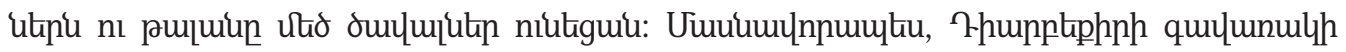

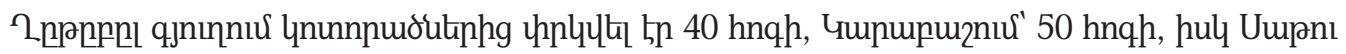

12 Unıju unŁnnư, 110-111.

13 “Армянскій вопросъ," 111.

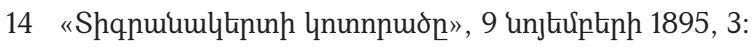

15 “Армянскій вопросъ," 112. 


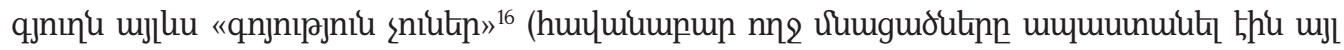

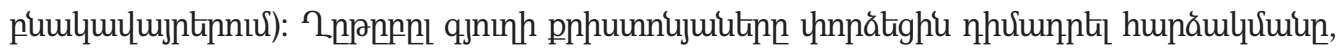

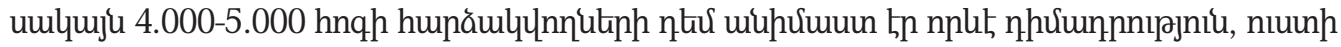

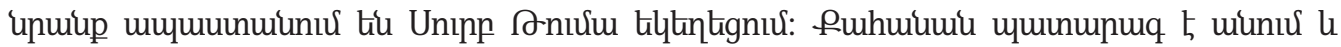

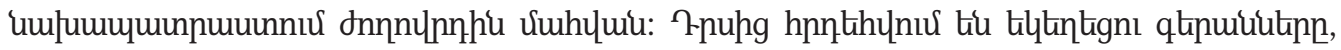

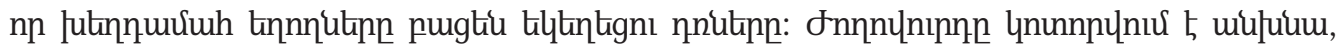

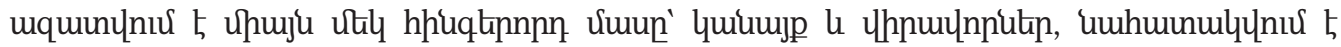

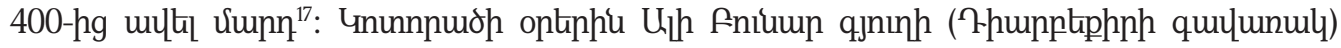

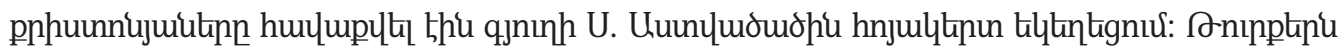

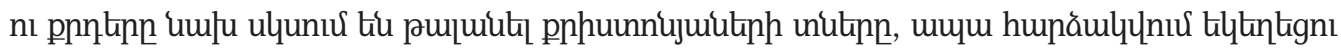

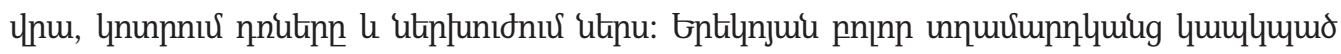

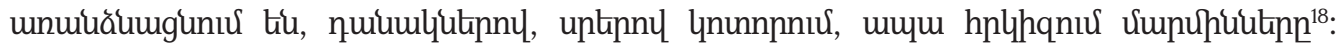

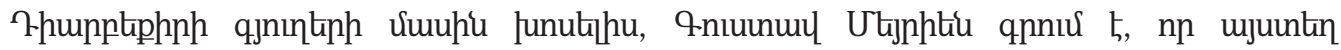

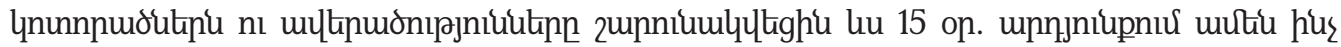
ullinlligis:

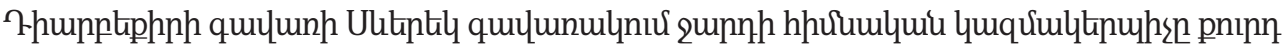

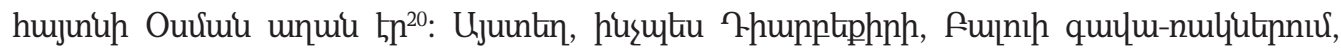

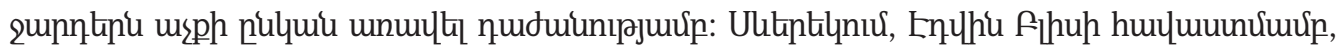

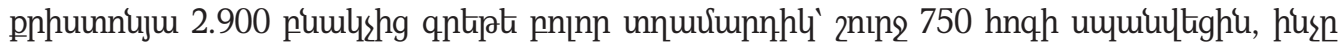

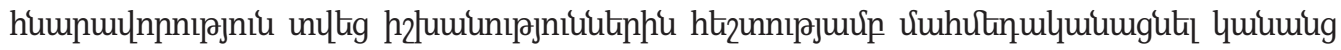

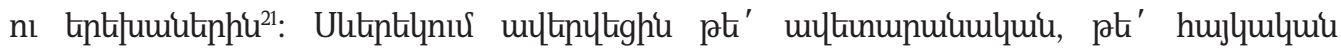

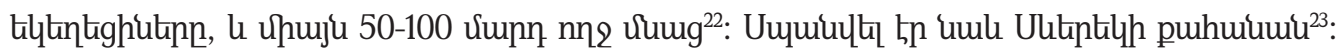

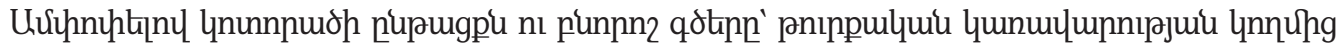

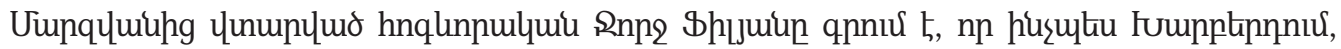

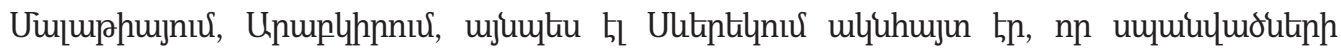

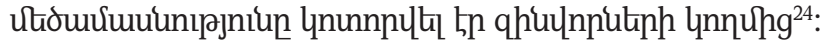

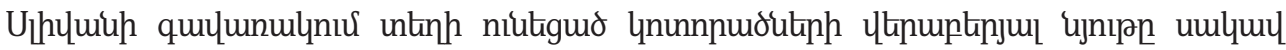

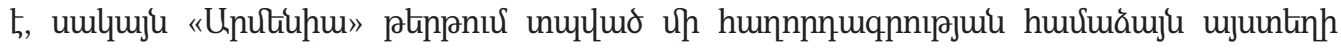

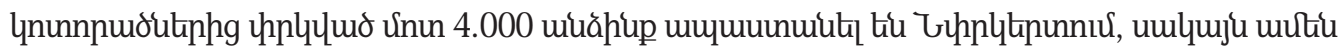

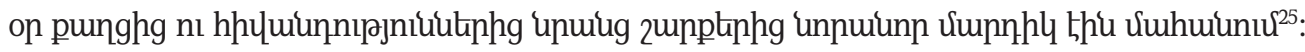

16 Filian, Armenia and Her People, 300.

17 unıju untnnux, 300:

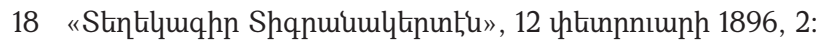

19 “Армянскій вопросъ," 110.

20 Verheij, "Diarbekir and the Armenian crisis," 135.

21 Bliss, Turkey and the Armenian Atrocities, 487.

Filian, Armenia and Her People, 299.

七nıju untinnư, 317:

টnıju untnnư, 263:

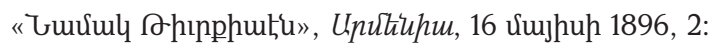




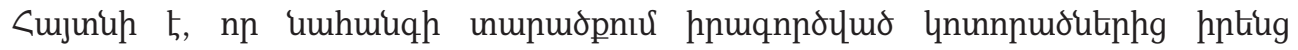

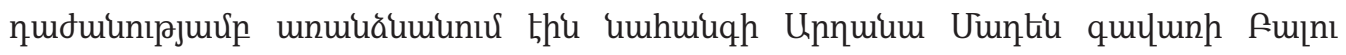

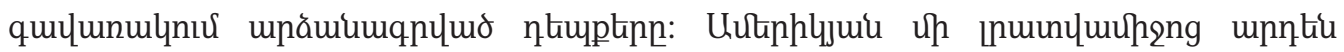

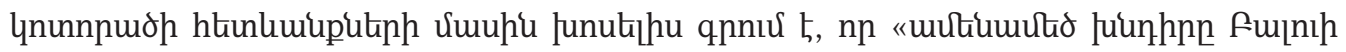

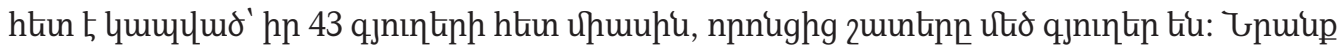

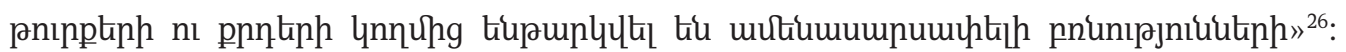

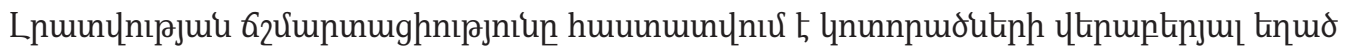

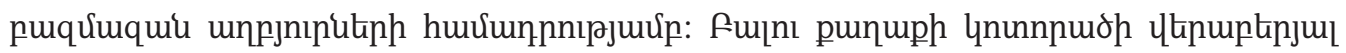

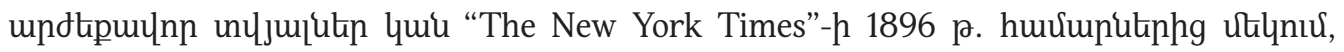

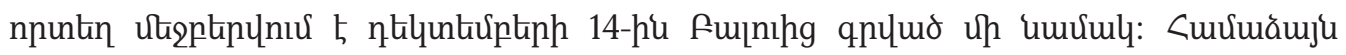

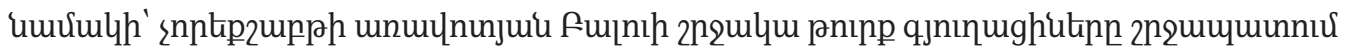

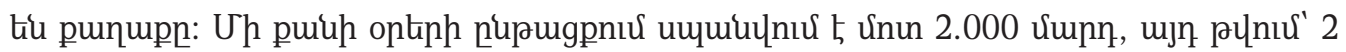

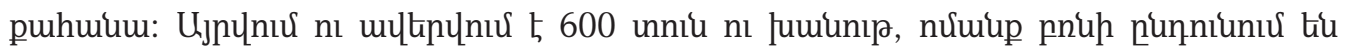

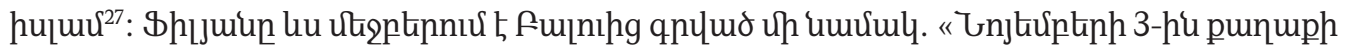

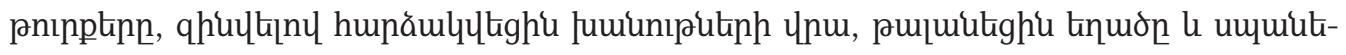

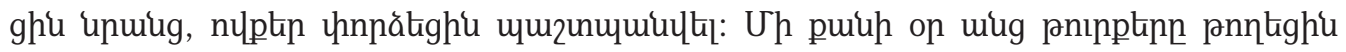

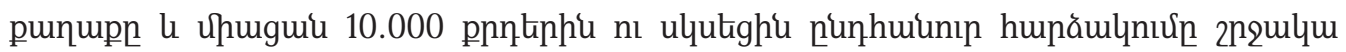

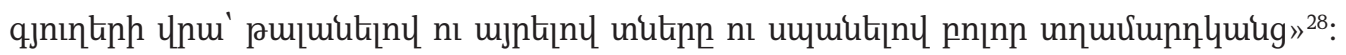

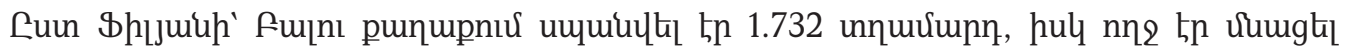

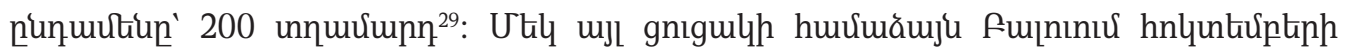

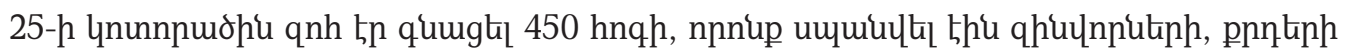

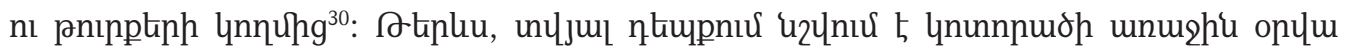

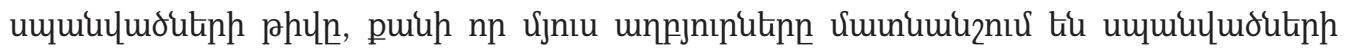

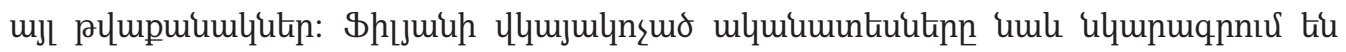

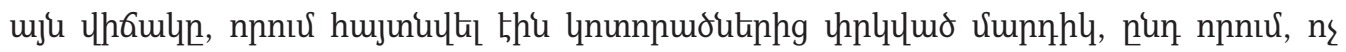
uhuju pun

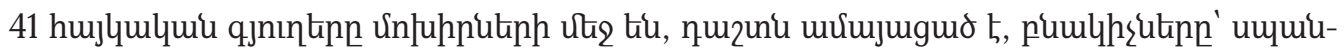

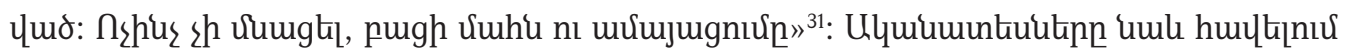

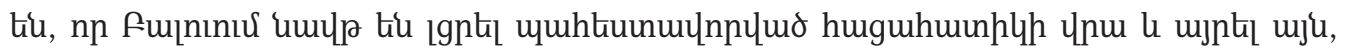

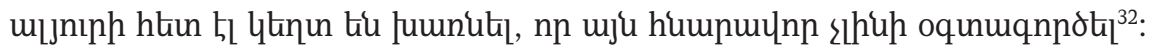

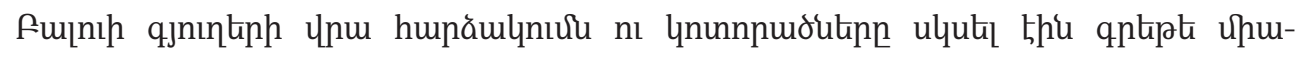

26 The Armenian Genocide: Prelude and Aftermath. As Reported in the U.S. Press. The New York Times (1890-1914), vol. 1, compiled and edited by Rev. Vahan Ohanian and Ara Ketibian (Mekhitarist Publication, 2018), 452.

27 七nıu unŁnnu, 429:

28 Filian, Armenia and Her People, 266.

29 টnıu unŁnnu, 267:

30 Rev. James W. Pierce, Story of Turkey and Armenia (Baltimore: R. H. Woodward Company, 1896), 486.

31 Filian, Armenia and Her People, 267.

32

unıu untnnư: 


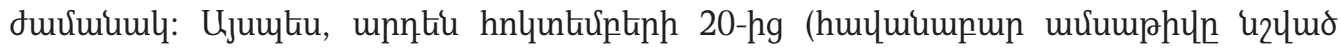

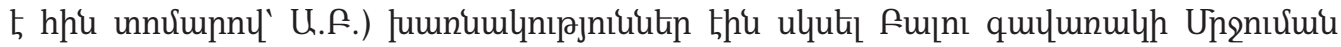

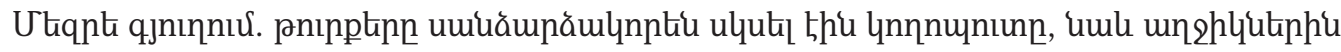

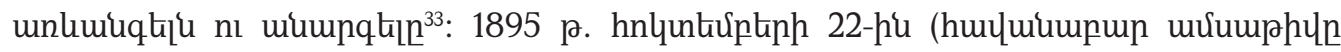

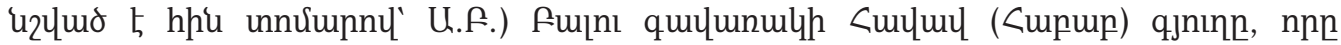

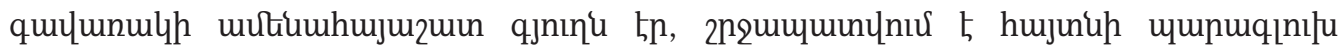

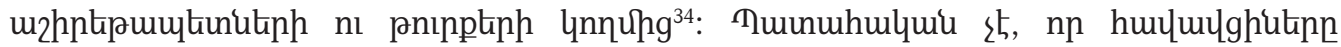

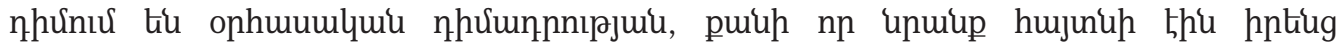

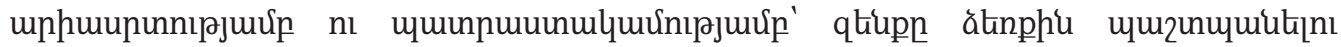

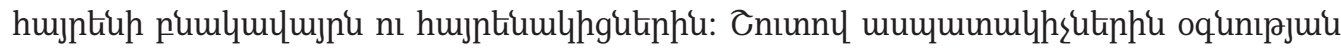

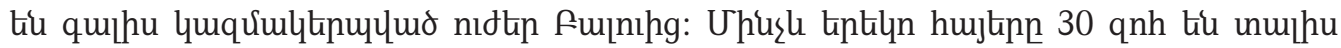

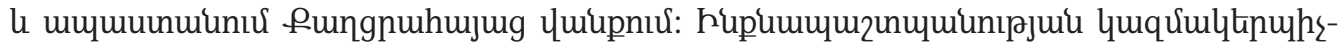

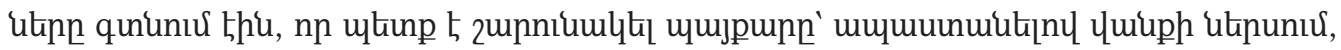

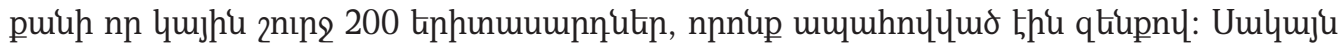

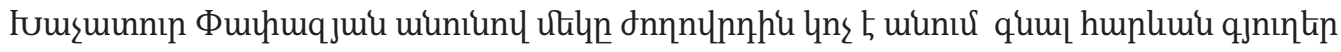

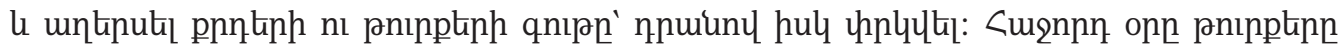

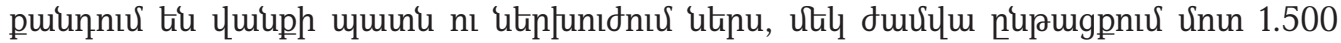

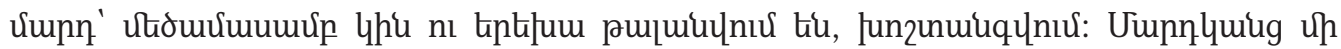

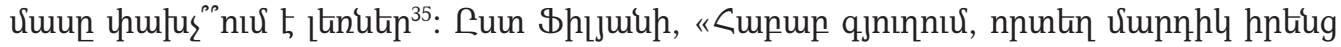

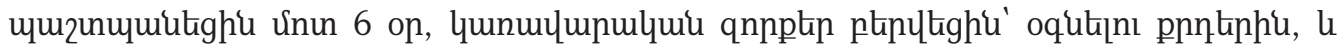

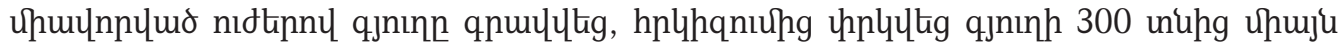

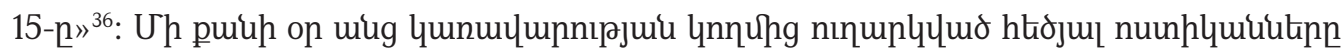

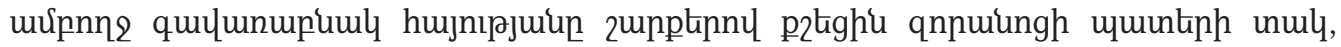

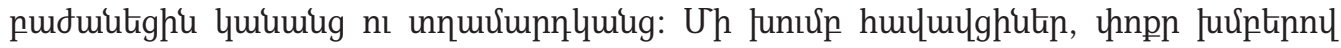

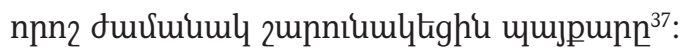

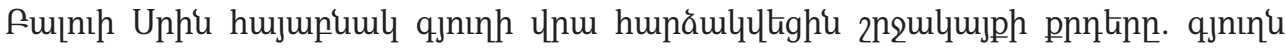

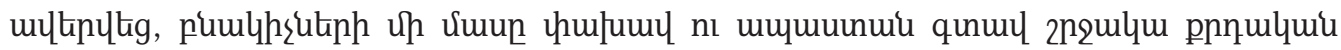

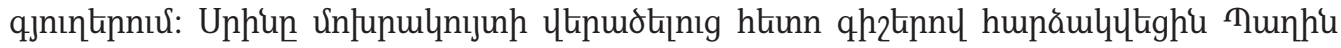

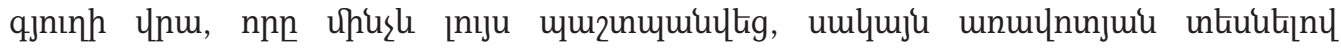

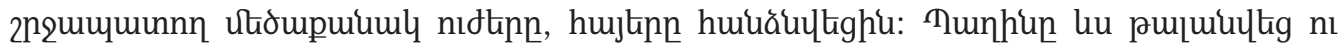

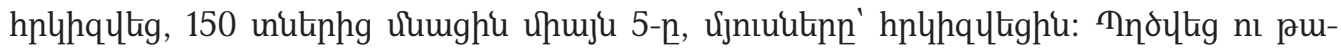

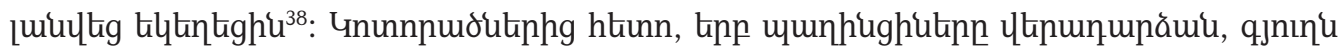
uulknuluitiph utis $\mathrm{kn}^{39}$ :

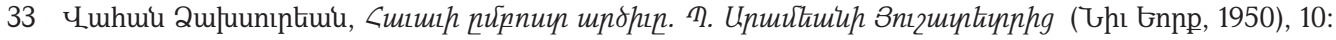

34 tnıju untinnu, 9:

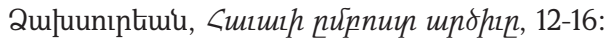

Filian, Armenia and Her People, 267.

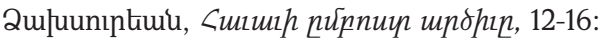




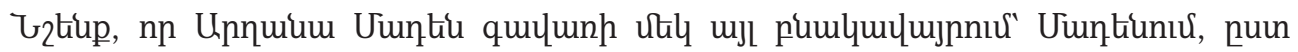

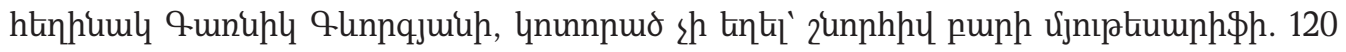

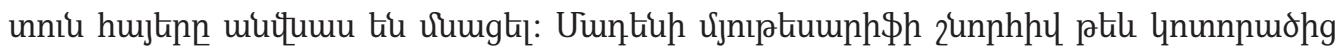

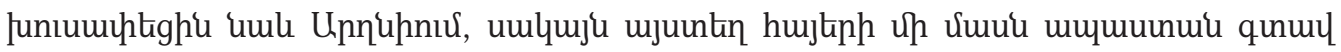

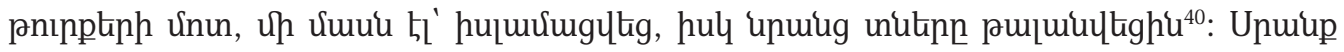

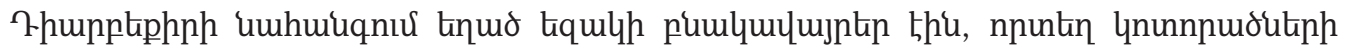

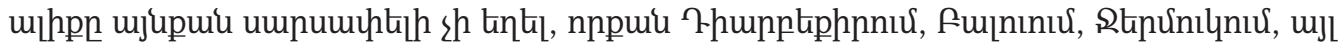

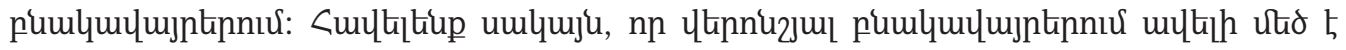

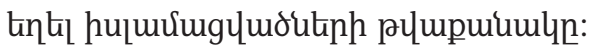

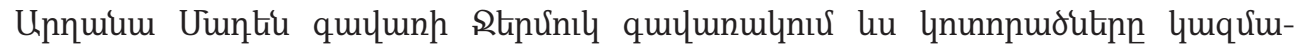

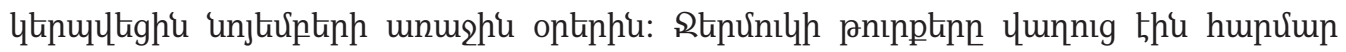

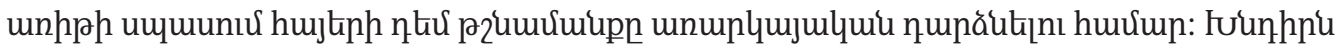

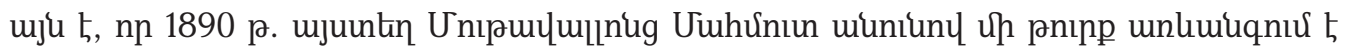

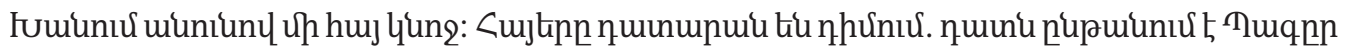

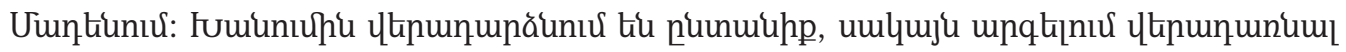

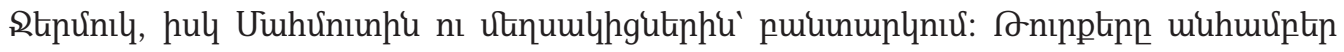

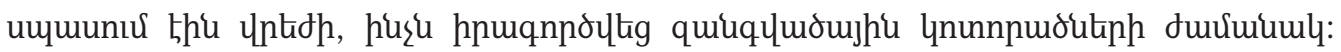

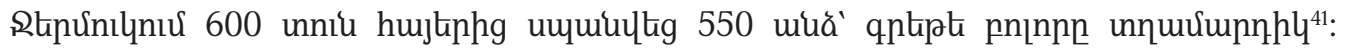

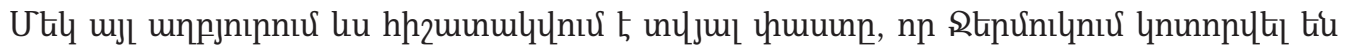

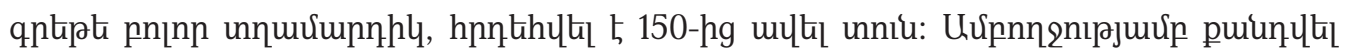

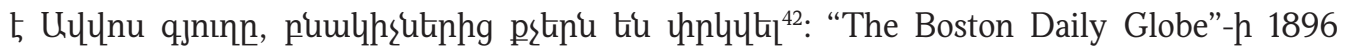

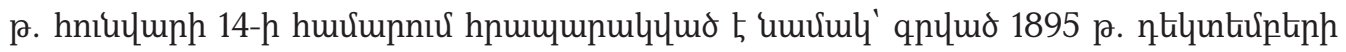

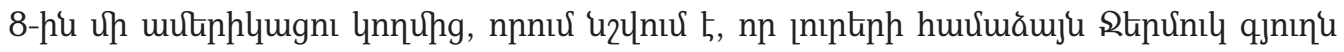

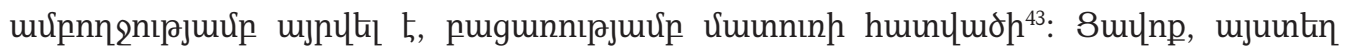

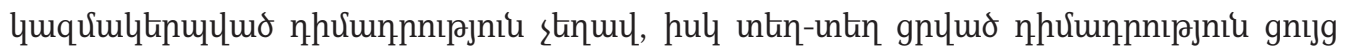

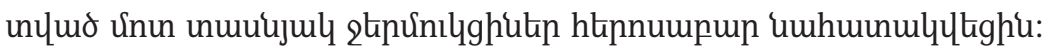

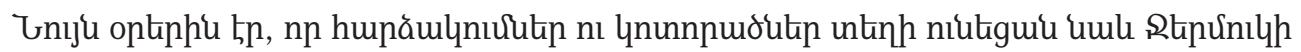

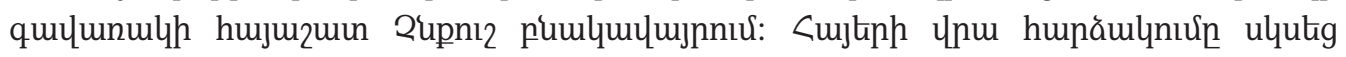

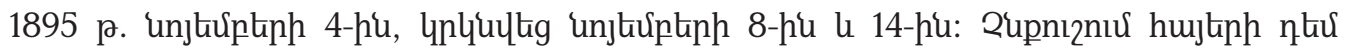

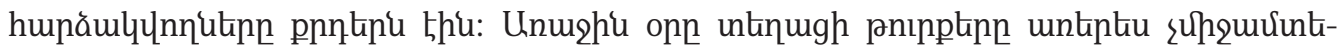

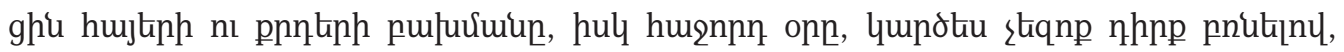

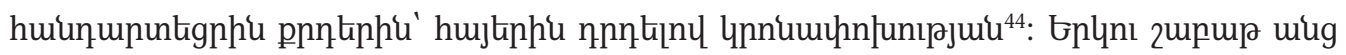

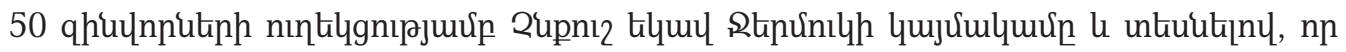

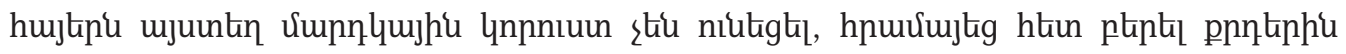

40 9tnnqtiuu, 2upnizmuminnıи, 64:

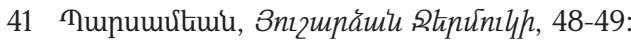

42 4tnnqtiuu, Qupnzzшщшипии, 64:

43 The Armenian Genocide: Prelude and Aftermath. As Reported in the U.S. Press. The Boston Daily Globe (18901922), vol. 1, compiled and edited by Rev. Vahan Ohanian and Ara Ketibian (Mekhitarist Publication, 2019), 222.

44 9.tnnqtiuu, Qupnгzшщштпии, 51: 


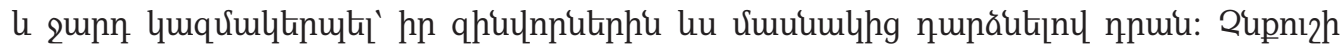

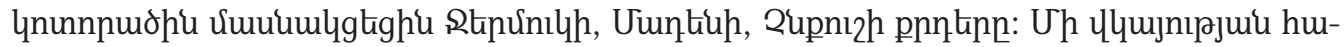

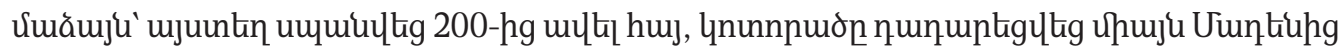

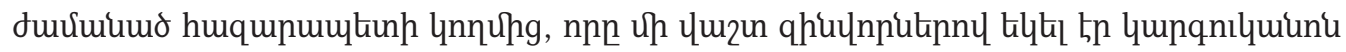

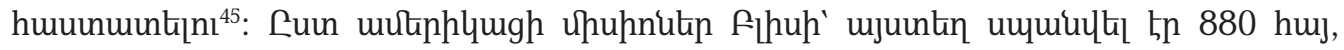

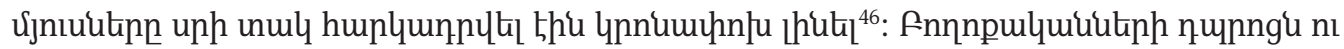

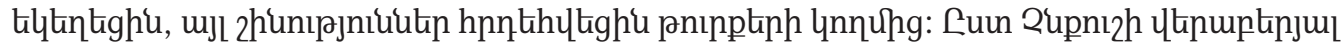

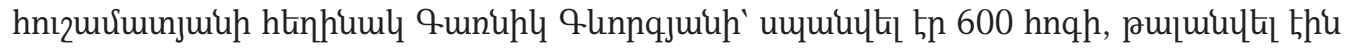

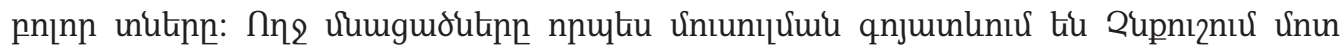

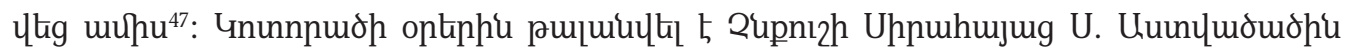

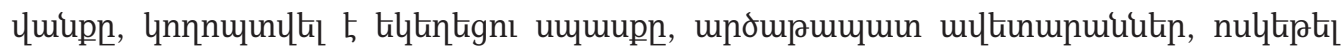

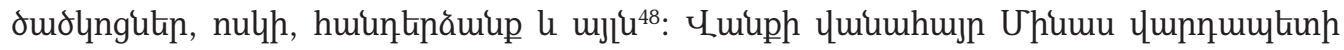

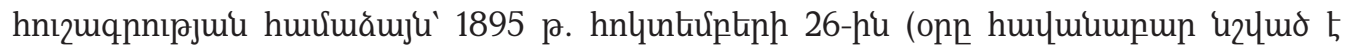

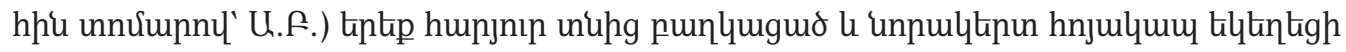

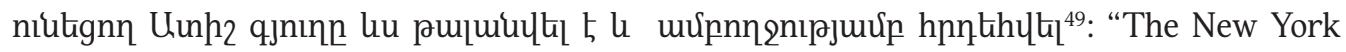

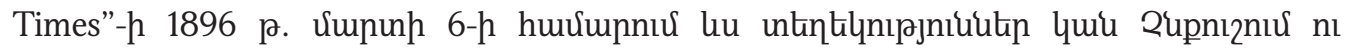

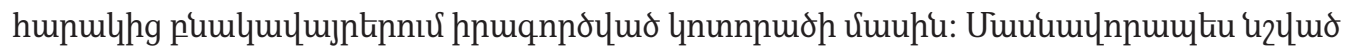

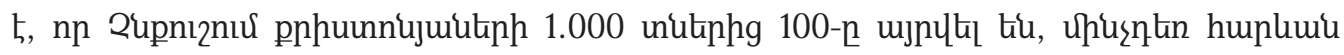

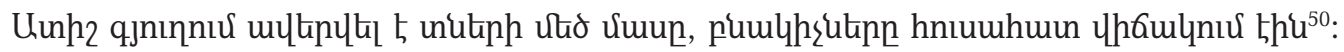

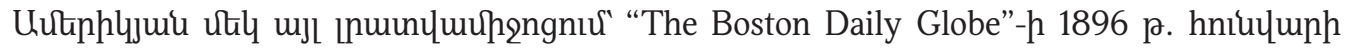

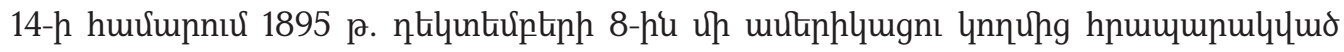

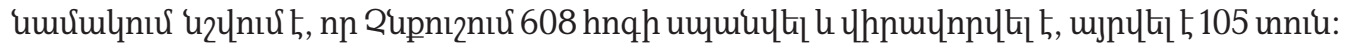

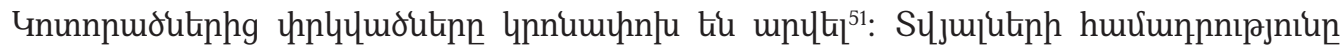

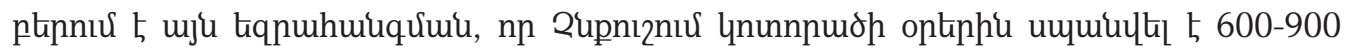

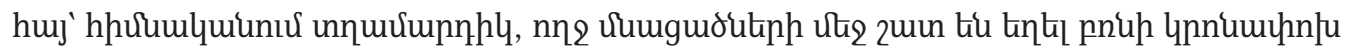

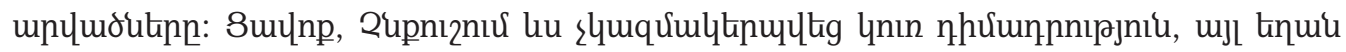

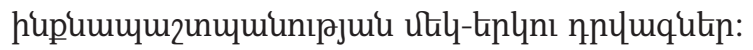

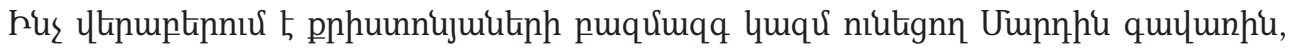

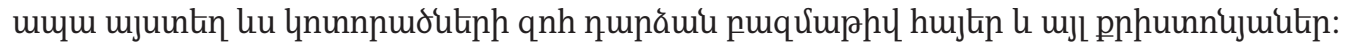

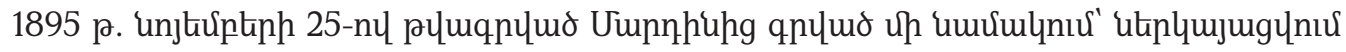

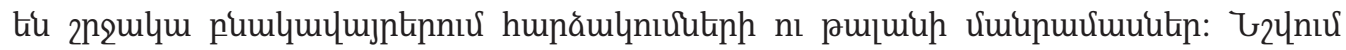

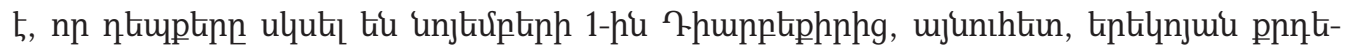

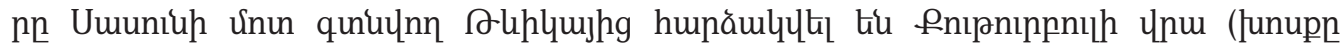

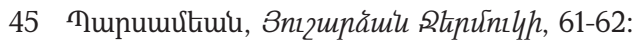

46 Bliss, Turkey and the Armenian Atrocities, 483.

47 9tnnqtiuu, 2upnizumminıu, 51:

48 七nıju untinnıu, 54-55:

49 七nıju untnnıu, 56:

50 The New York Times (1890-1914), 452.

51 The Boston Daily Globe (1890-1922), 222. 


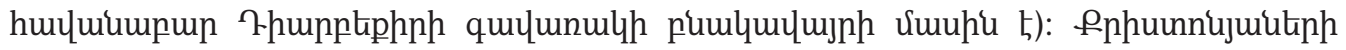

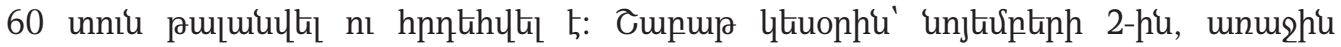

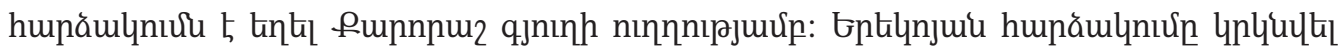

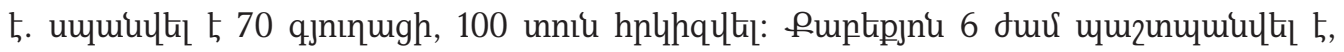

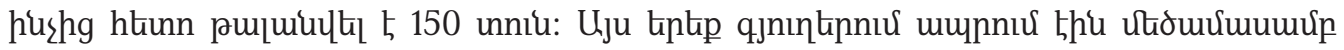

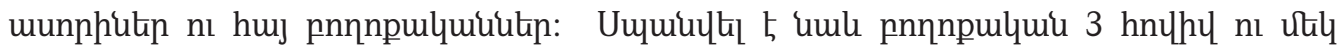

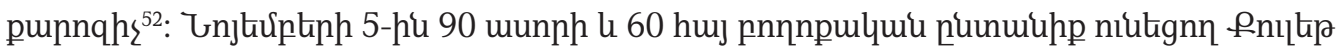

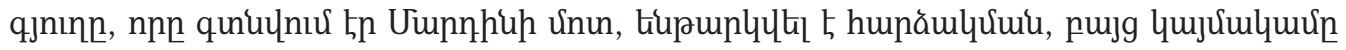

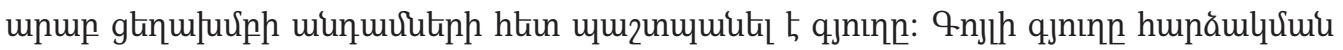

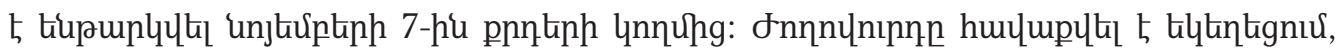

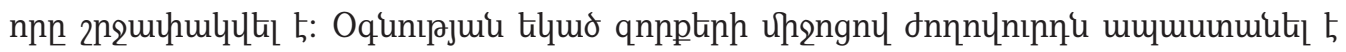
Uunnhunius:

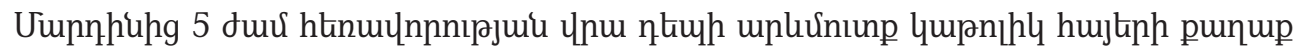

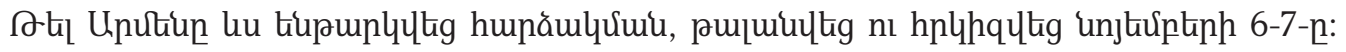

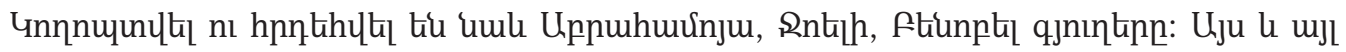

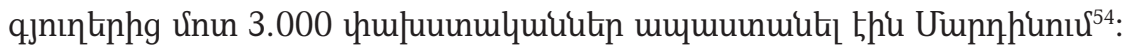

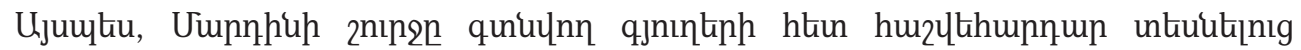

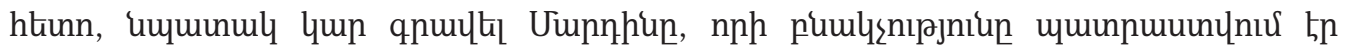

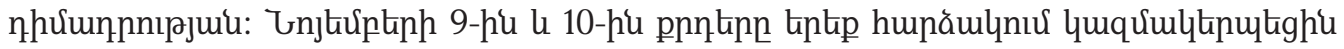

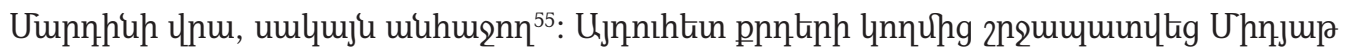

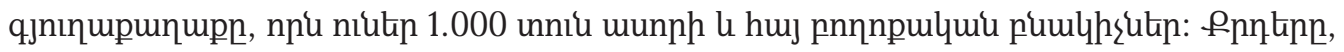

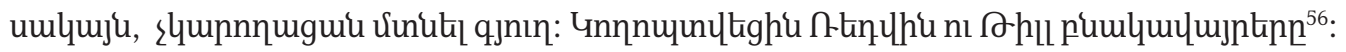

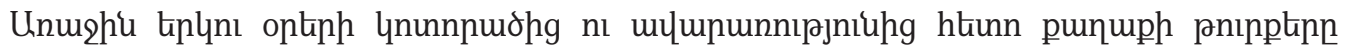

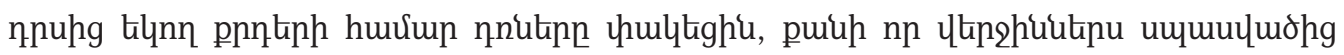

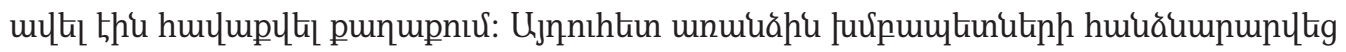

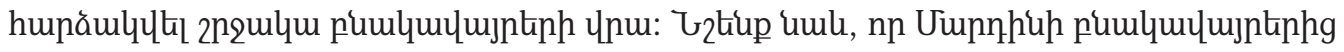

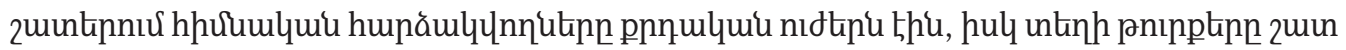

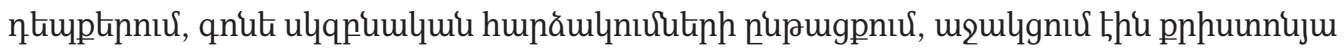

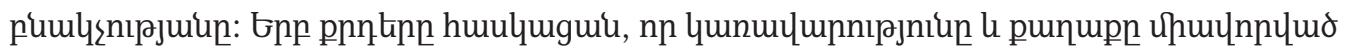

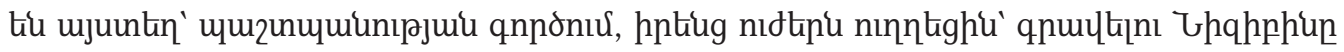

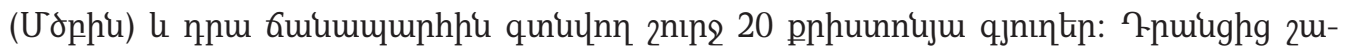

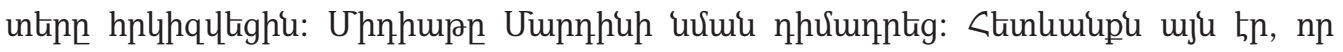

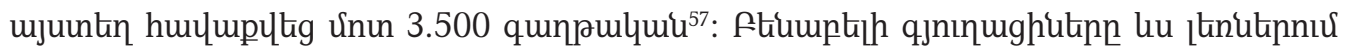

52 Frederik Greene, Armenian Massacres or the Sword of Mohammed (Philadelphia: International Publishing Co., 1896), 276.

53 unuju untinnux:

54 The New York Times (1890-1914), 358-359.

55 Bliss, Turkey and the Armenian Atrocities, 475.

56 The New York Times (1890-1914), 358-359.

57 Bliss, Turkey and the Armenian Atrocities, 476. 


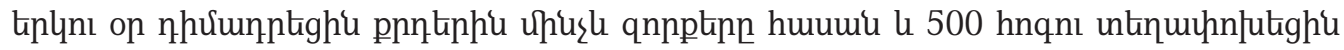

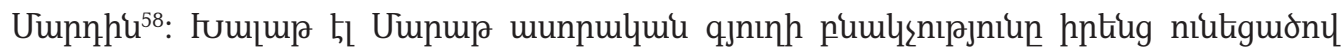

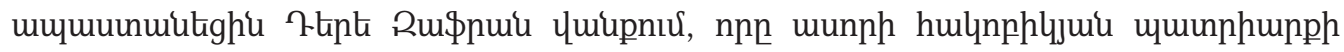

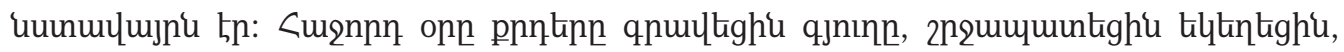

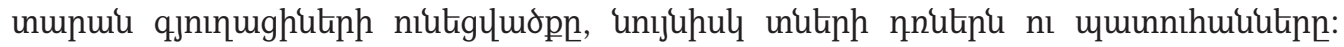

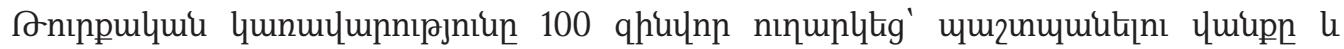

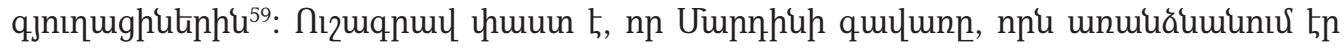

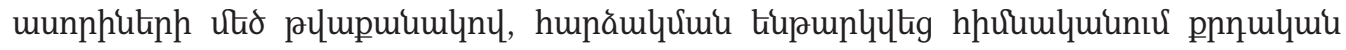

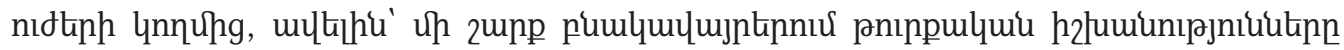

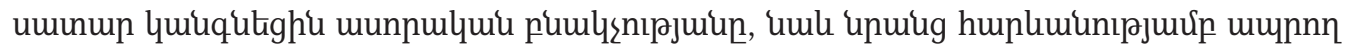
uJl pnhuunnujuiutiph:

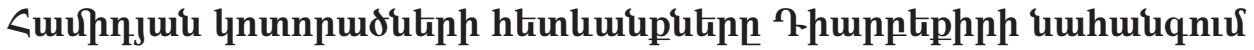

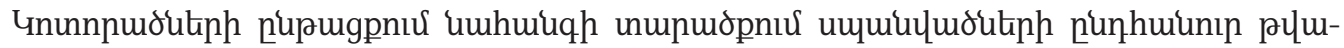

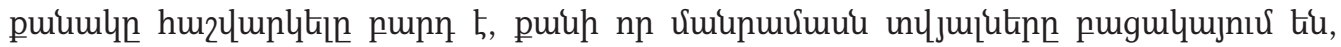

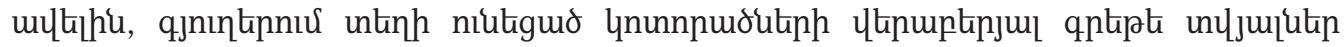

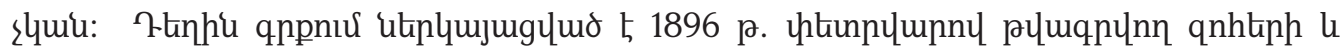

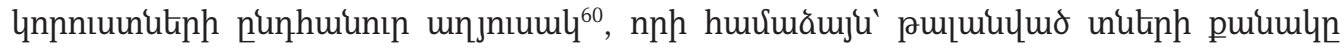

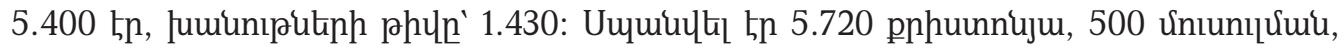

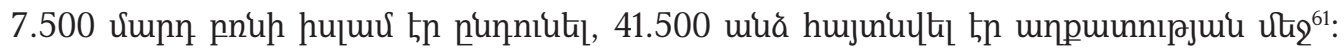

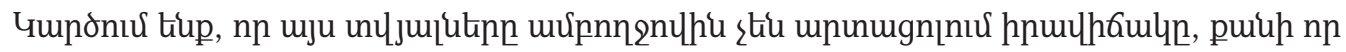

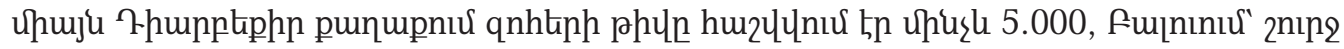

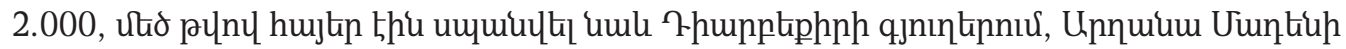

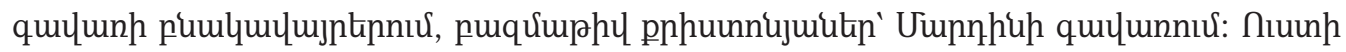

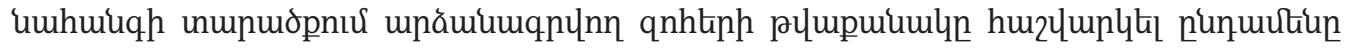

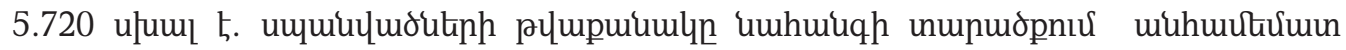

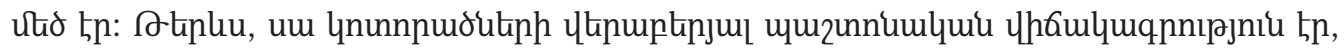

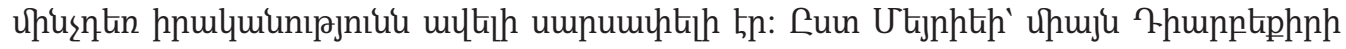

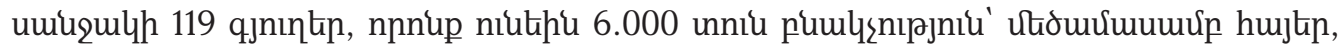

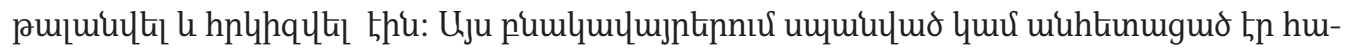

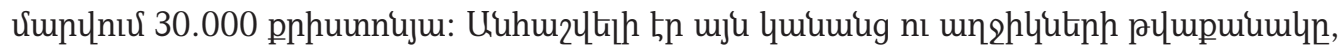

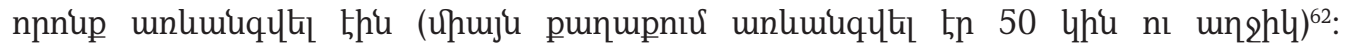

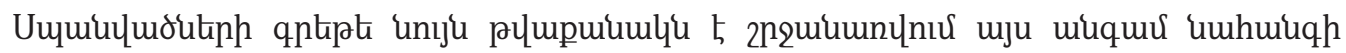

58 Greene, Armenian Massacres, 276.

59 Znıju untinnux:

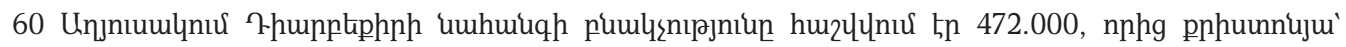
133.600-n:

61 “Армянскій вопросъ,” 124.

62 Unıju untinnıu, 112: 


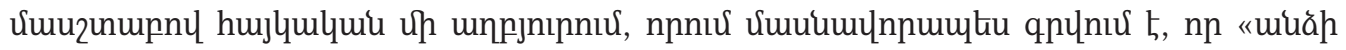

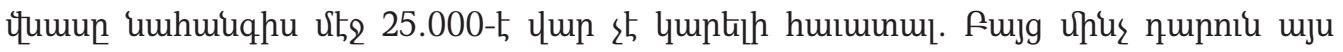

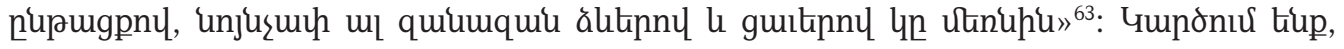

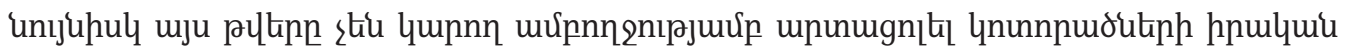

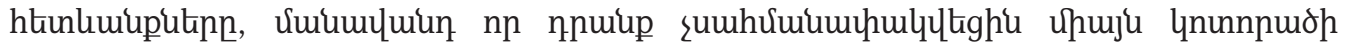

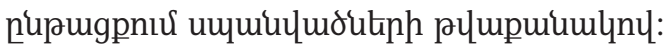

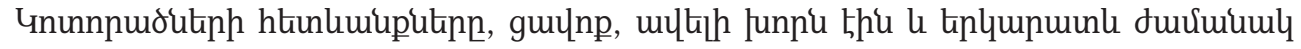

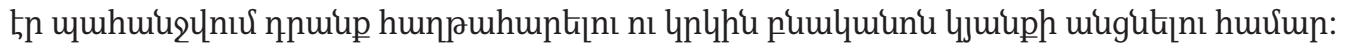

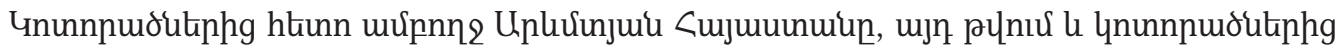

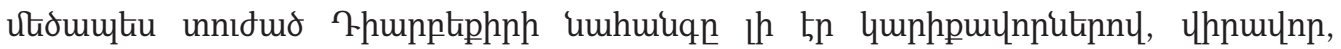

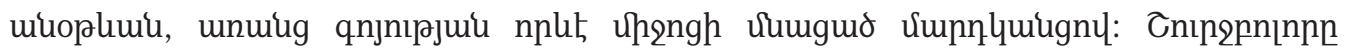

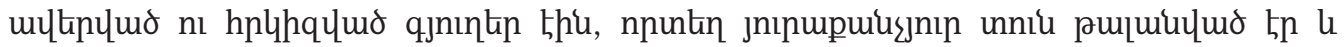

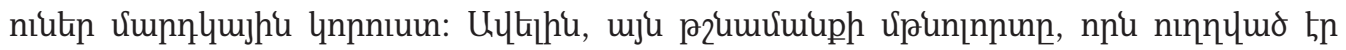

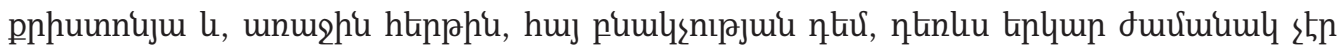

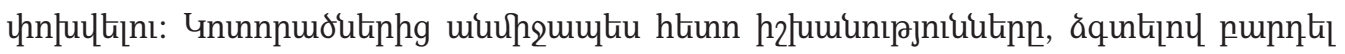

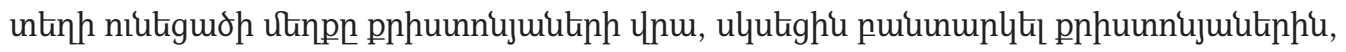

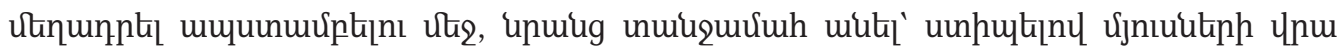

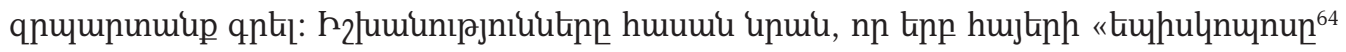

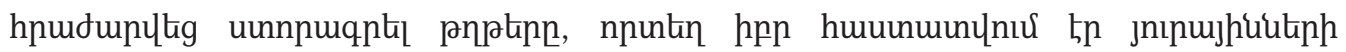

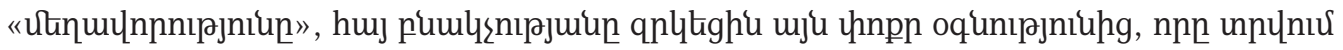

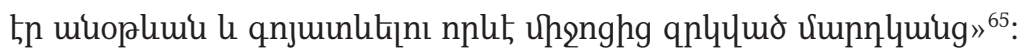

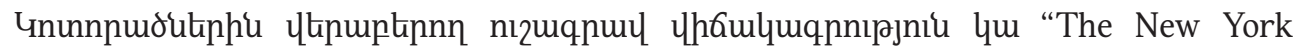

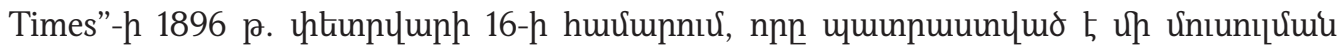

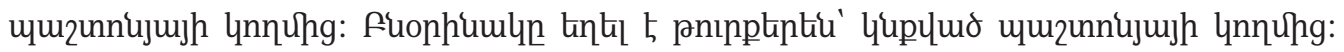

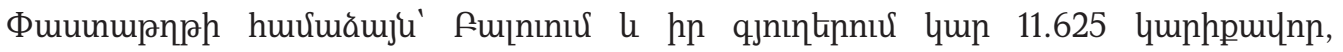

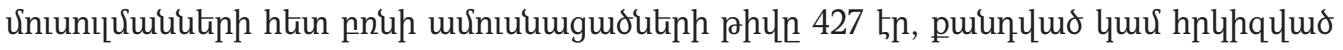

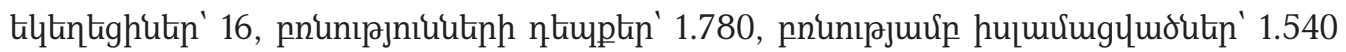

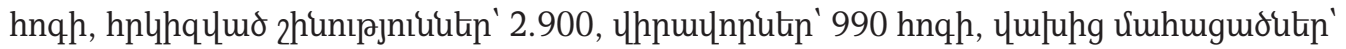

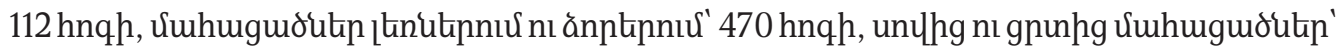

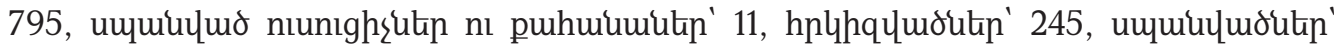

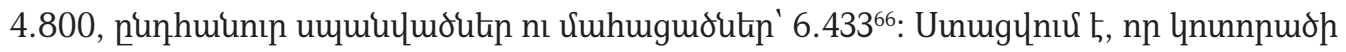

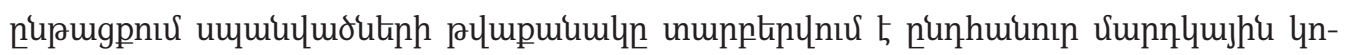

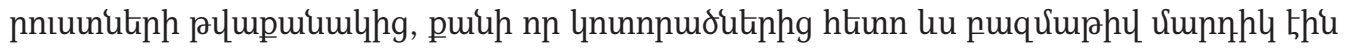

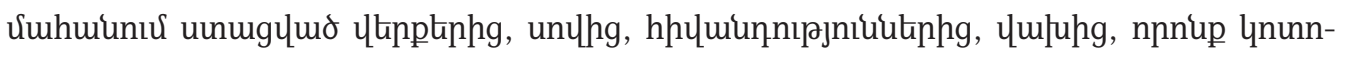

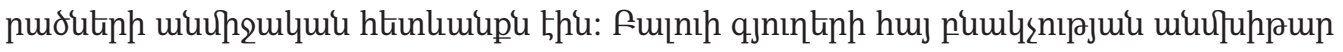

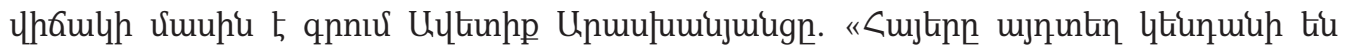

63 «Stinklumqhn Shqnumultinuth», 15 htinnnimph 1896, 2:

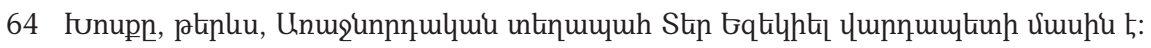

65 “Армянскій вопросъ," 112.

66 The New York Times (1890-1914), 430-431. 


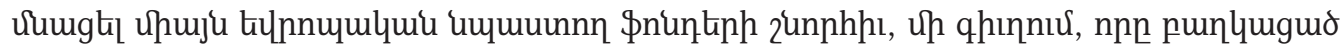

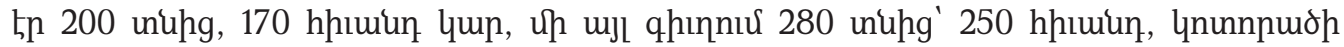

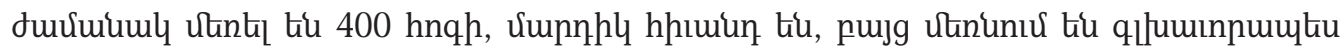

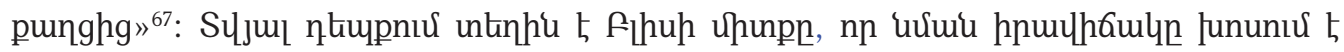

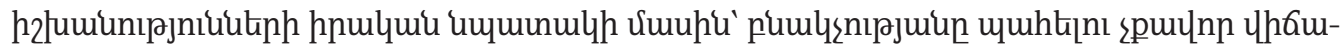

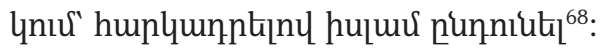

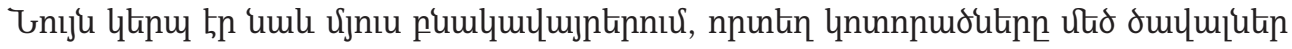

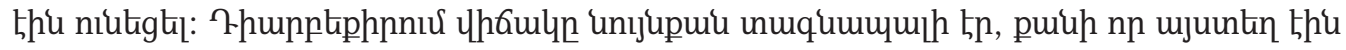

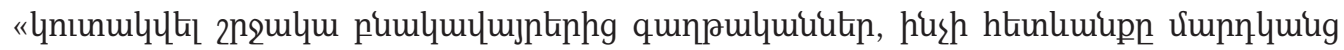

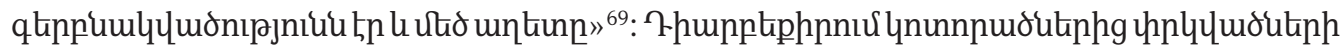

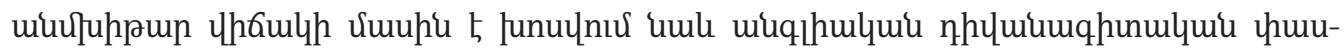

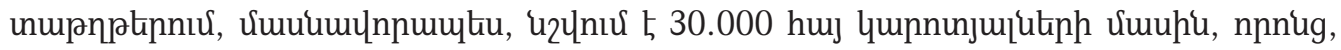
tipt zoqutl, lufinutiu punghg, u2

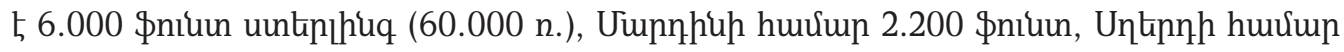

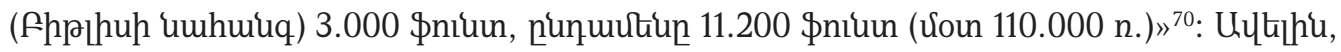

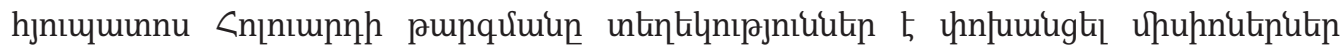

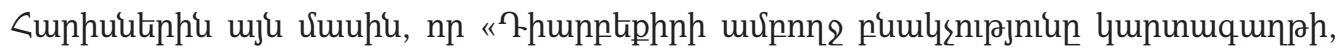

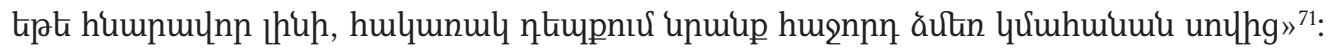

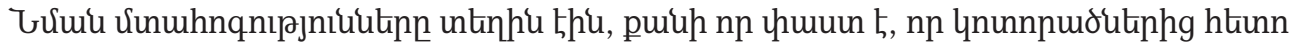

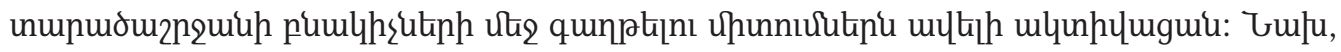

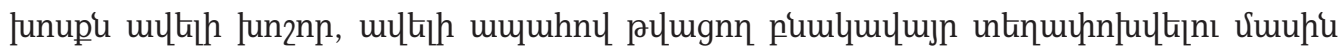

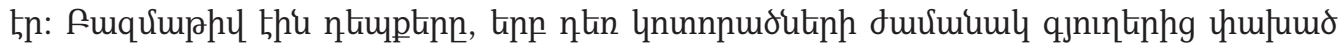

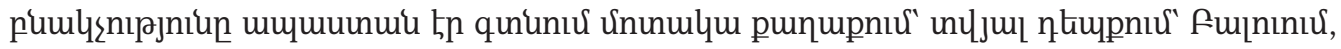

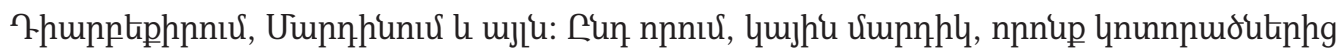

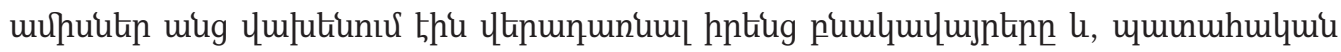

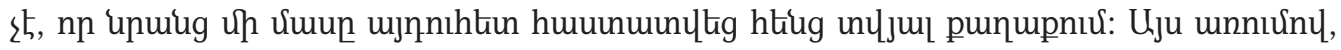

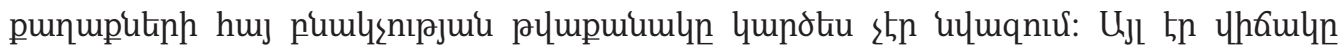

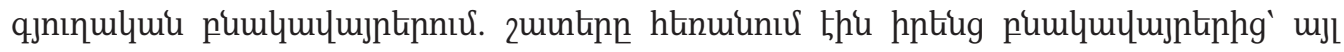

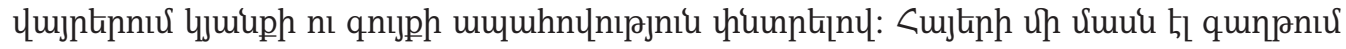

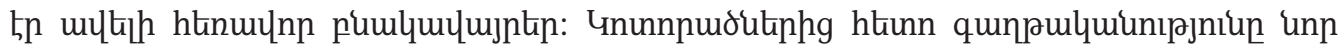

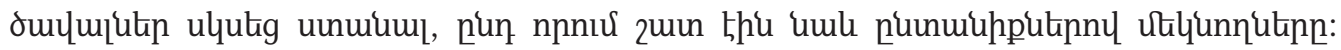

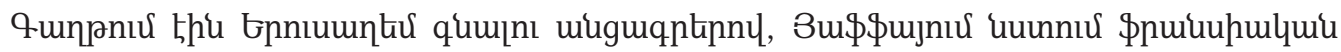

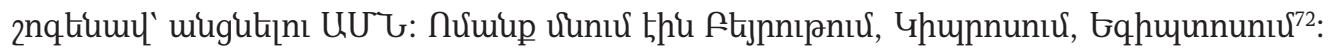

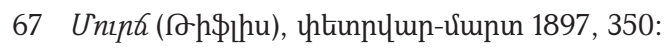

68 Bliss, Turkey and the Armenian Atrocities, 484.

69 Report: America's Relief Expedition to Asia Minor under the Red Cross (Washington, 1896), 86.

70 Unınk, цhinnцun-\{umun 1897, 354:

71 Harris and Harris, Letters from the Scenes, 102.

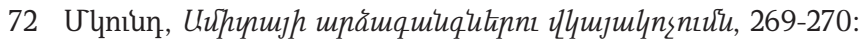




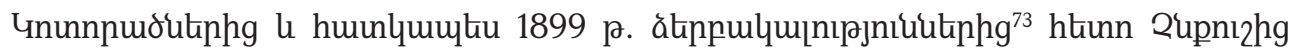

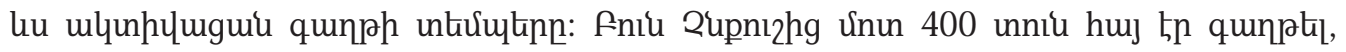

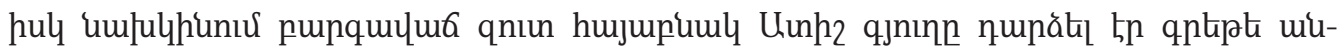

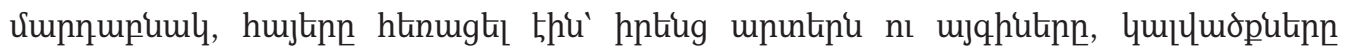

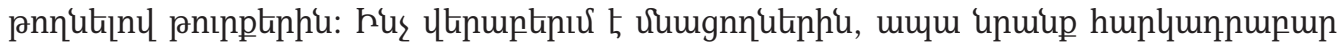

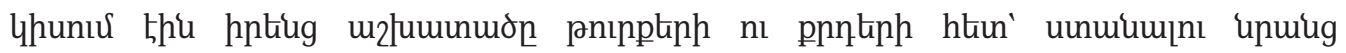

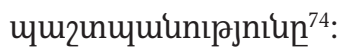

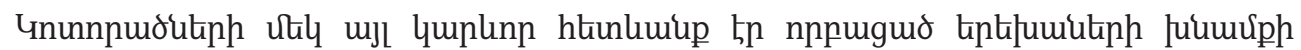

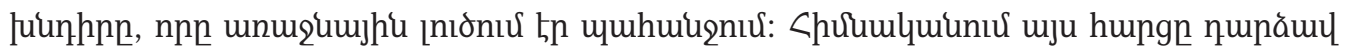

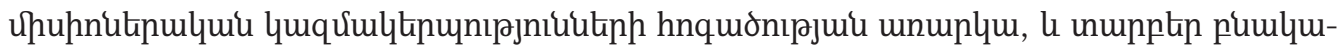

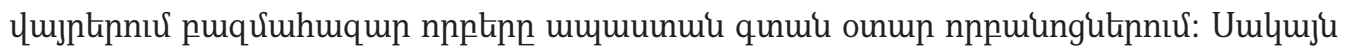

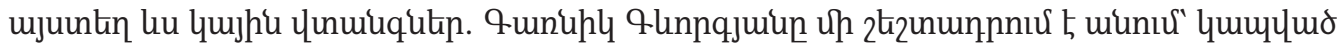

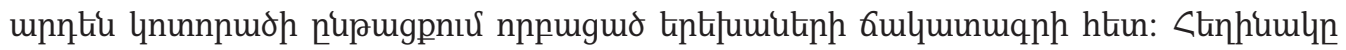

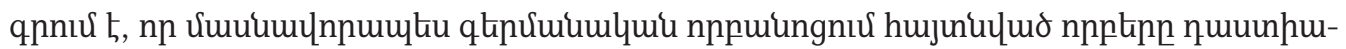

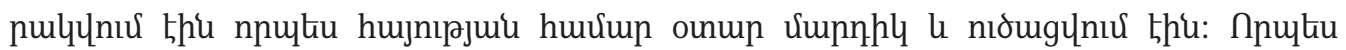

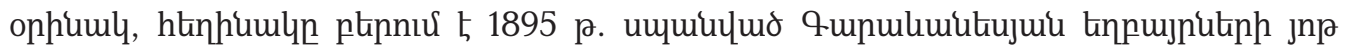

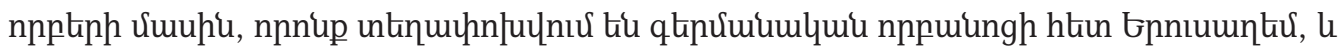

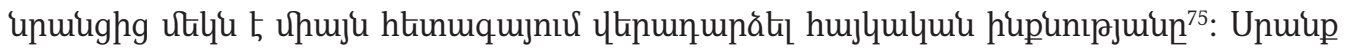

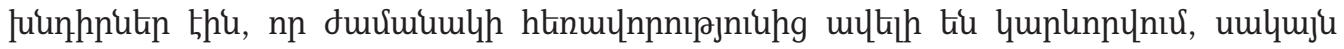

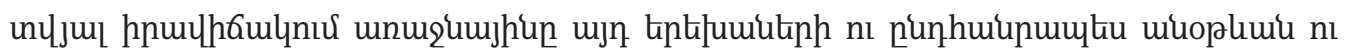

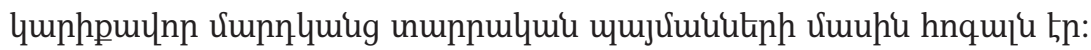

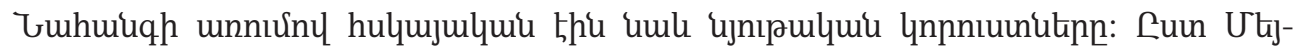

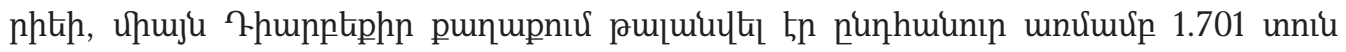

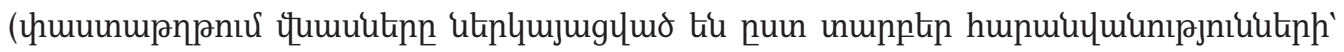

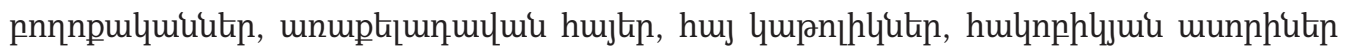

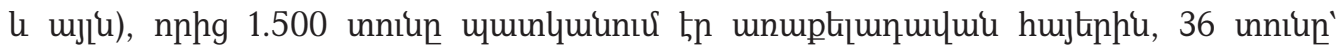

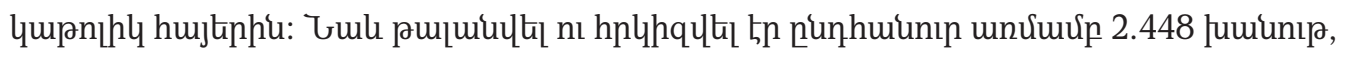

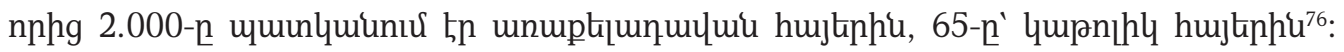

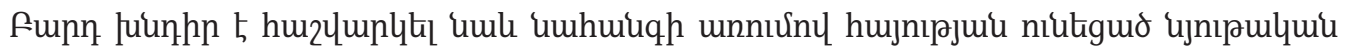

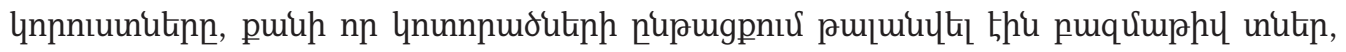

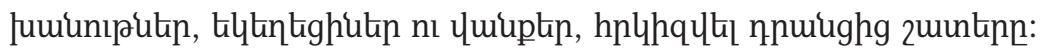

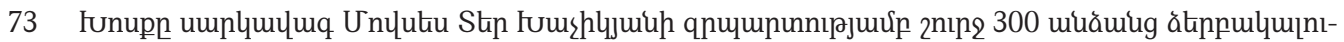

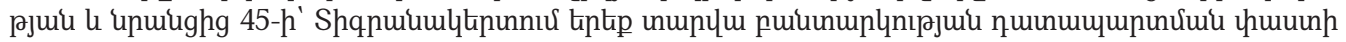
umuhu t' nnuku «htnumnhumlumuutiph»:

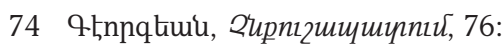

75 Єnıju untnnuर, 66:

76 “Армянскій вопросъ,"111. 


\section{คnup цpnuuunnjunıpjniu}

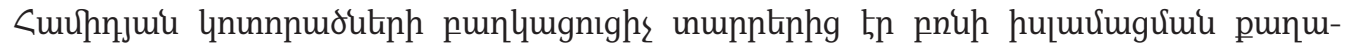

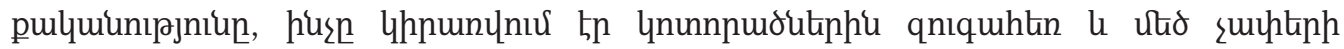

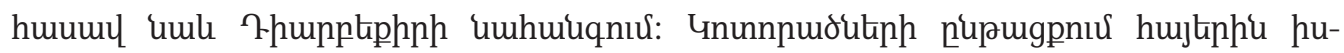

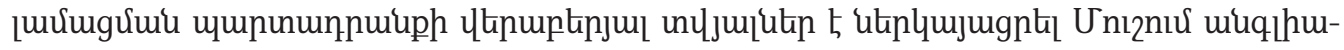

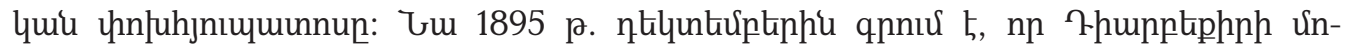

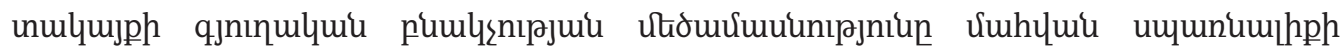

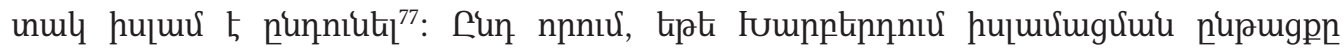

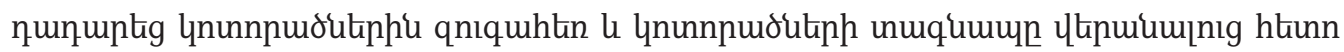

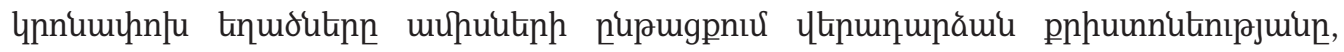

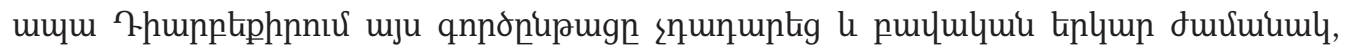

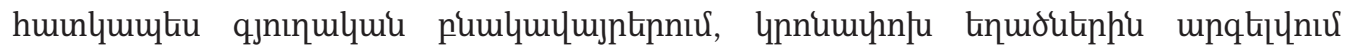

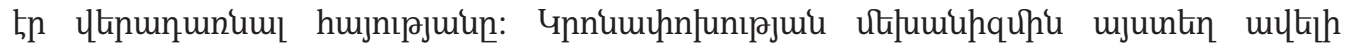

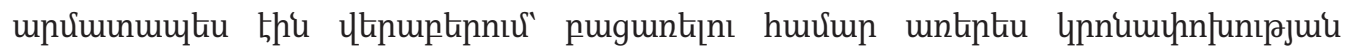

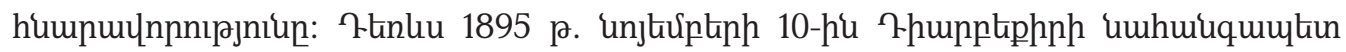

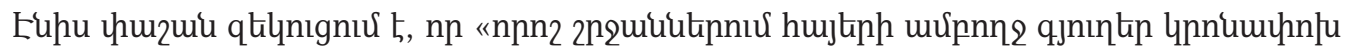

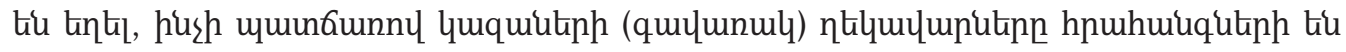

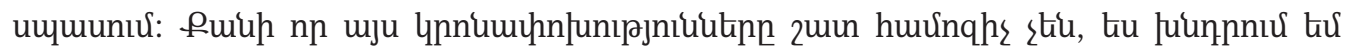

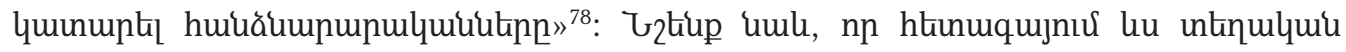

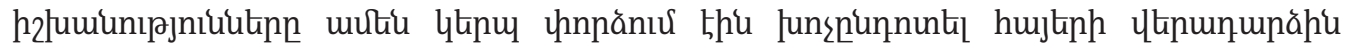

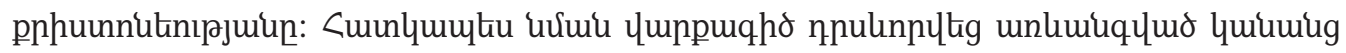

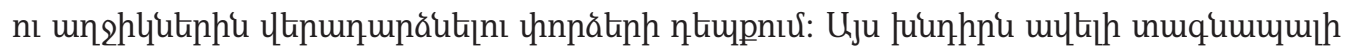

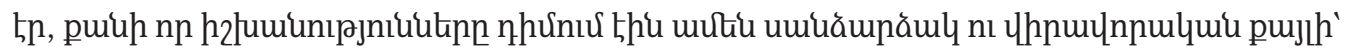

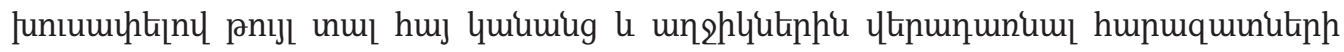

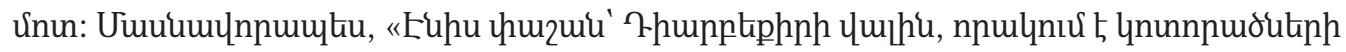

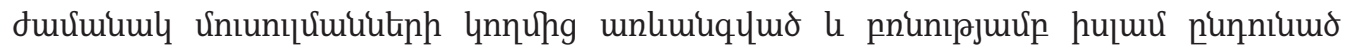

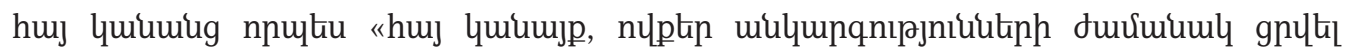

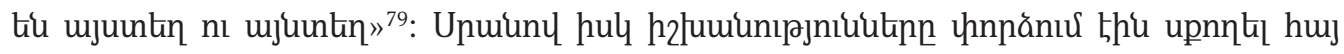

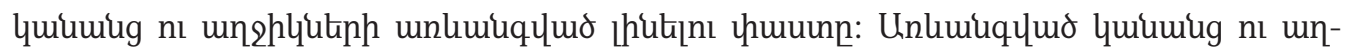

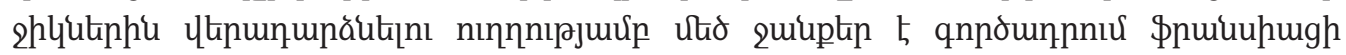

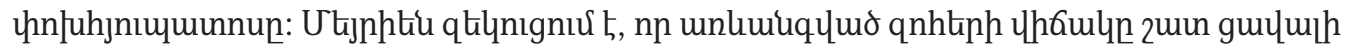

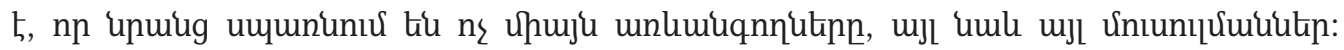

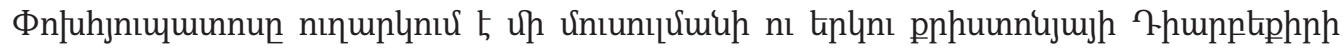

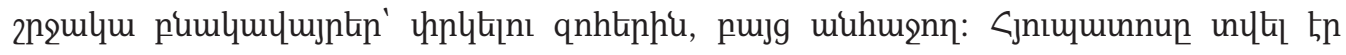

77 Unıu untnnıu, 119:

78 Selim Deringil, "The Armenian Question is Finally Closed": Mass Conversions of Armenians in Anatolia during the Hamidian Massacres of 1895-1897," Comparative Studies in Society and History 51, no. 2 (2009): 352.

79 Єnıju untnnıu, 350: 


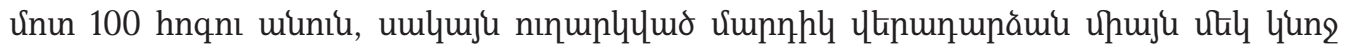

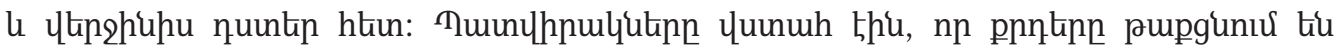

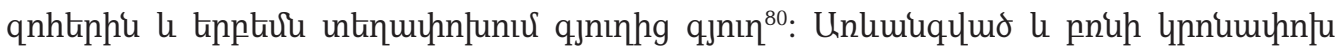

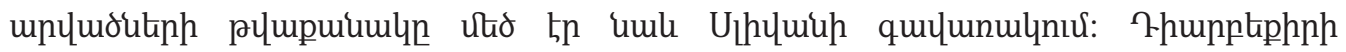

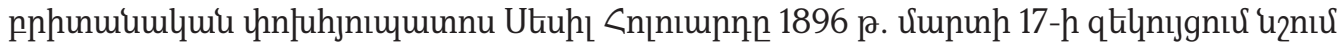

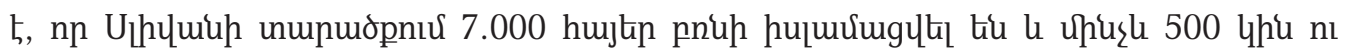

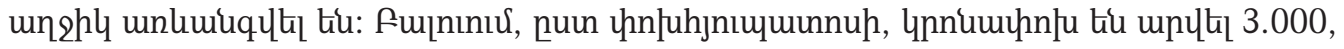

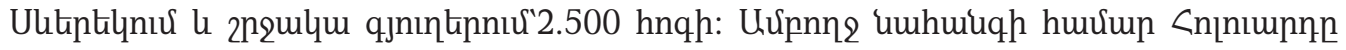
hü2

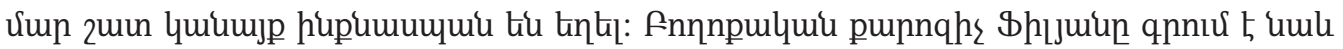

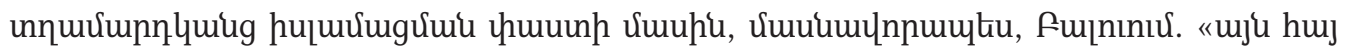

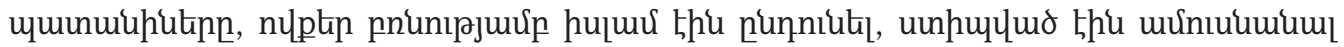

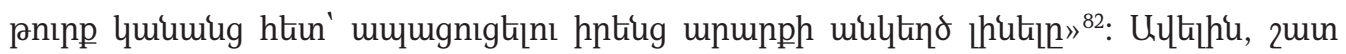

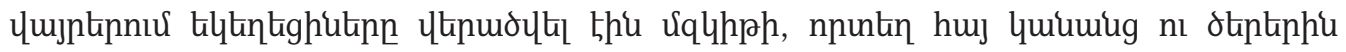

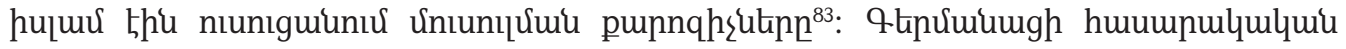

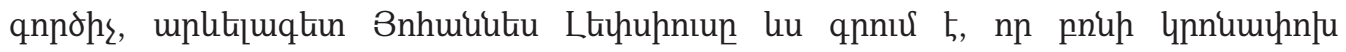

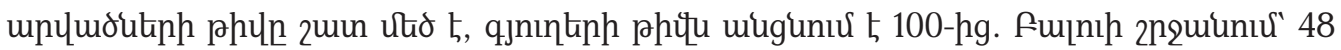

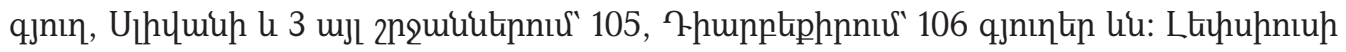

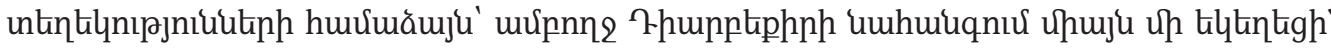

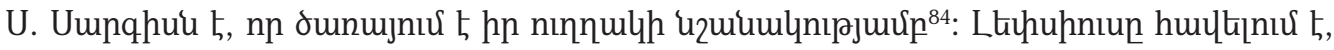

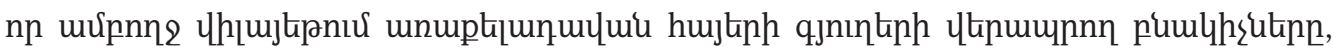

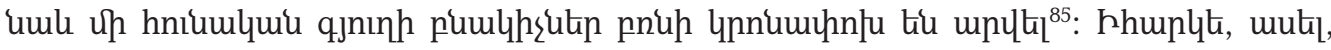

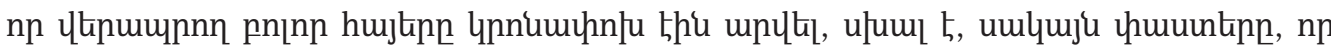

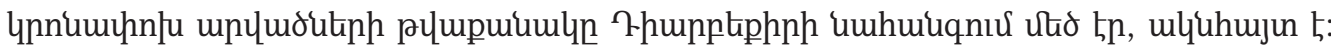

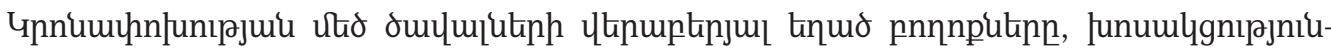

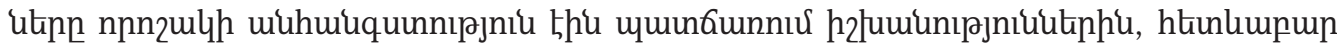

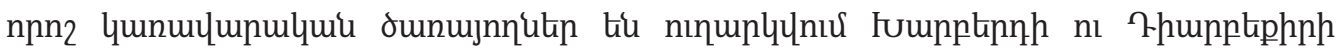

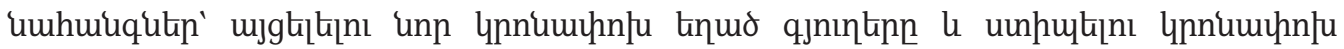

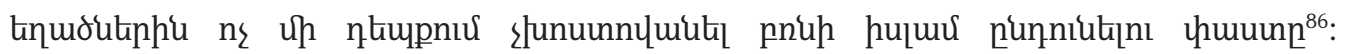

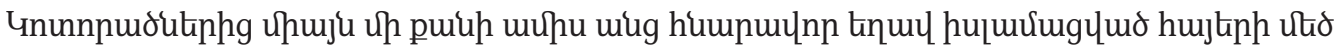

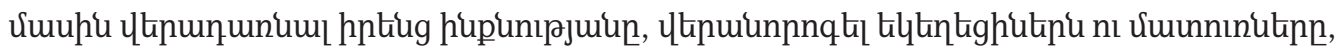
dtukin luquumliknukl:

80 tnıju untinnư, 362:

81 Vahagn Dadrian, The History of the Armenian Genocide: Ethnic Conflict from the Balkans to Anatolia to the Caucasus (Providence, RI \& Oxford: Berghahn Books, 1995), 156.

82 Filian, Armenia and Her People, 267.

83 Unıu untnnuर, 268:

84 Johannes Lepsius, Armenia and Europe (London: Hodder \& Stoughton, 1897), 37.

85 Unıju untinnuर, 12:

86 tnıju untinnư, 65: 


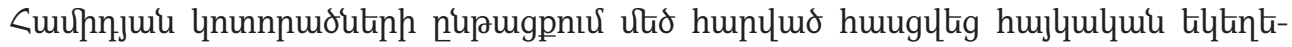

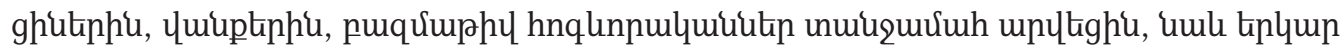

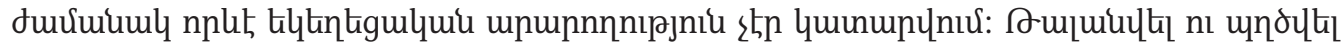

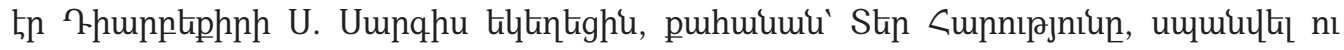

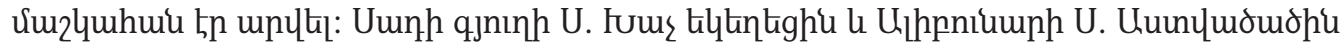

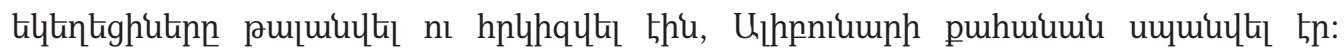

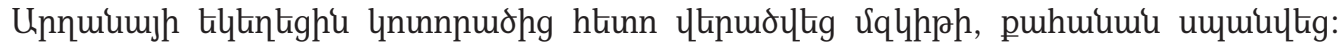

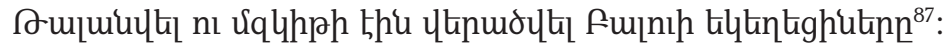

\section{Gqpulugnıpjniututp}

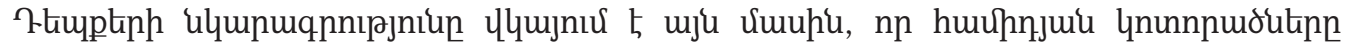

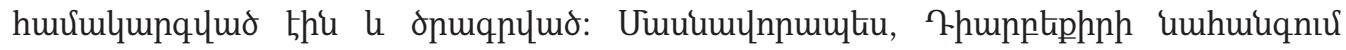

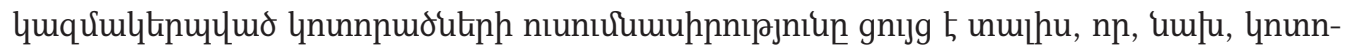

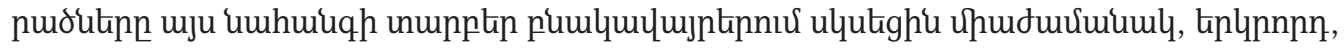

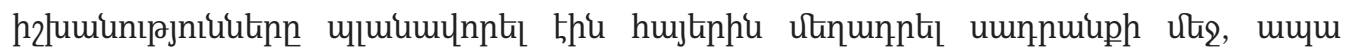

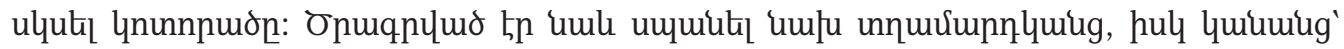

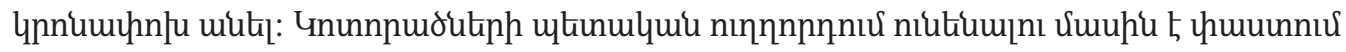

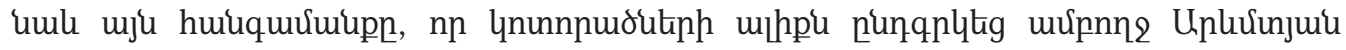

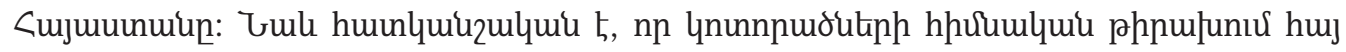

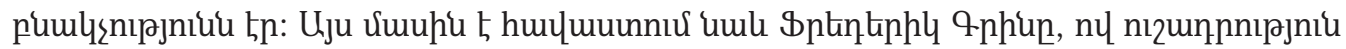

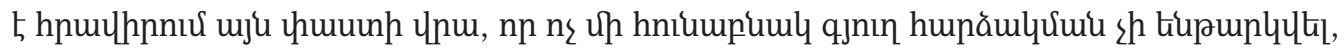

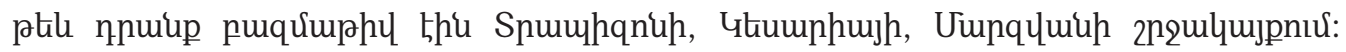

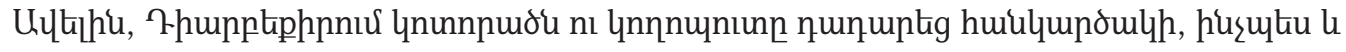

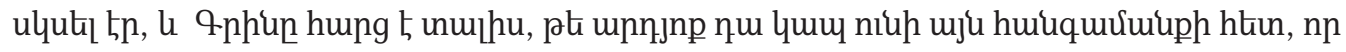

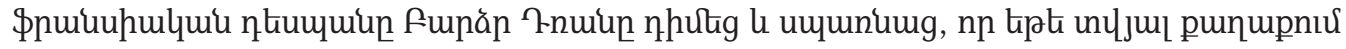

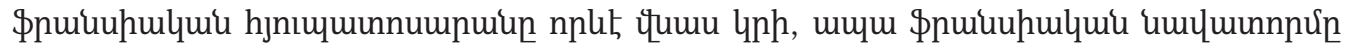

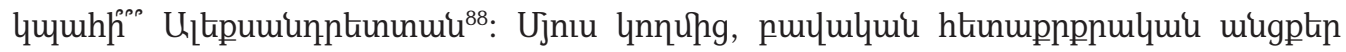

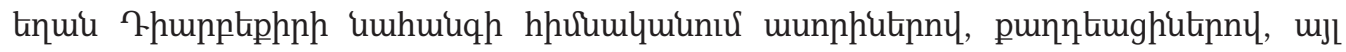

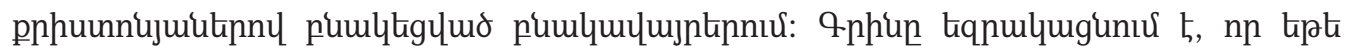

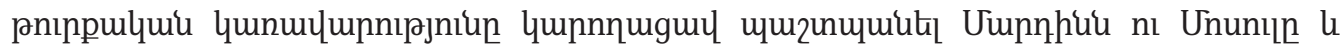

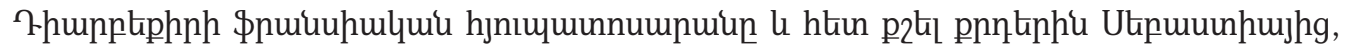

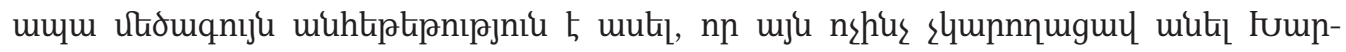

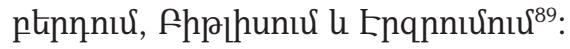

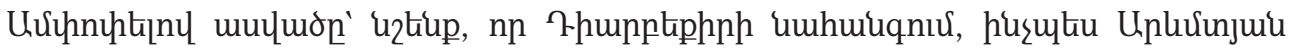

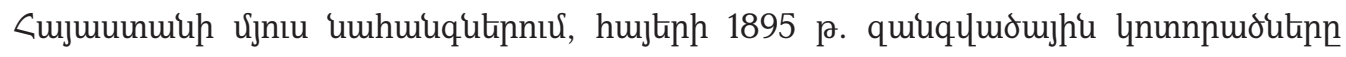

87 Lepsius, Armenia and Europe, 275-276.

88 Greene, Armenian Massacres, 305.

89 Unıju untinnux: 


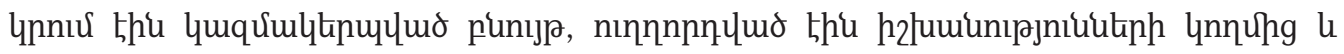
nnwug hnuqnnơ

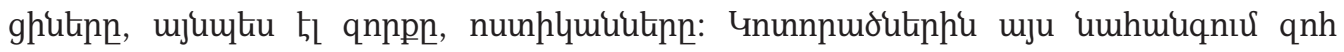

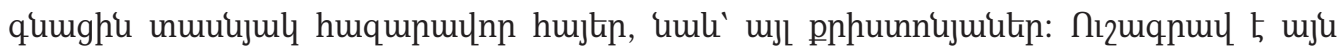

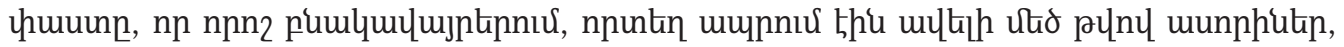

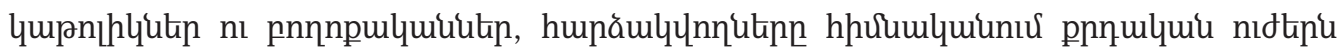

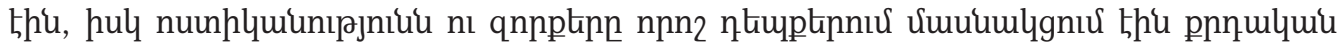

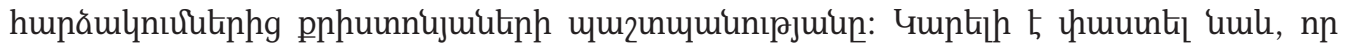

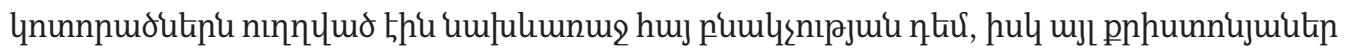

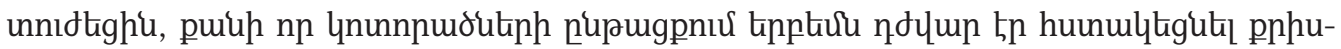

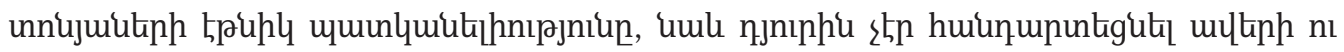

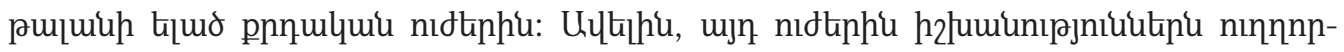

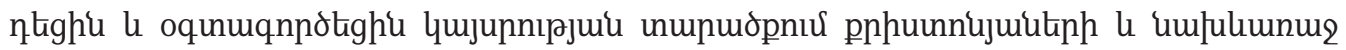

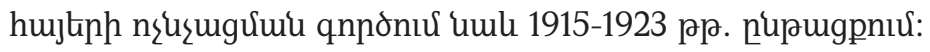

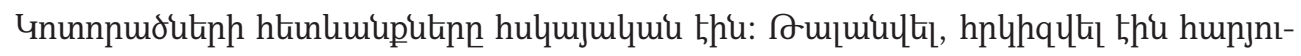

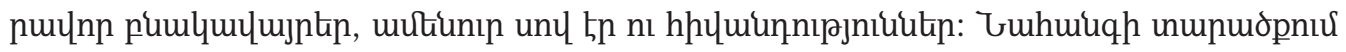

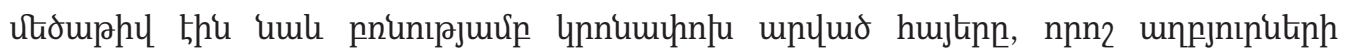

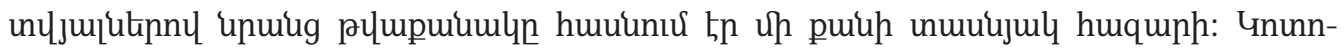

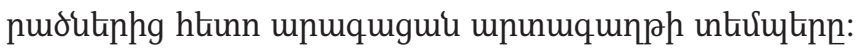

Arpine R. Bablumyan

$\mathrm{PhD}$ in history

\title{
THE ARMENIAN POPULATION OF THE DIARBEKIR PROVINCE OF WESTERN ARMENIA DURING HAMIDIAN MASSACRES
}

\begin{abstract}
SUMMARY
Key words: Western Armenia, Diarbekir, Tigranakert, Amid, Balu, Severek, Arghana Maden, Islamization by force, massacres of Armenians.

In the province of Diarbekir, as in other provinces of Western Armenia, the massacres of Armenians in 1895 were organized by the authorities and carried out by ordinary Muslim citizens as well as by the army and police. In this province, as well as in others, tens of thousands of Armenians were killed, as were hundreds of other Christians. It can also be assumed that the massacres were aimed primarily at the Armenian population, while other Christians suffered, as it was sometimes difficult to verify their ethnicity. It was not easy to stop the Kurds during the massacres. It is noteworthy that in some localities where Assyrians, Catholics and Protestants lived in greater numbers, the attackers were mainly Kurds, and the police and troops took part in the defense of population.
\end{abstract}


The consequences of the massacres were not limited to the number of people who were killed: thousands of people died after they ended due to illness, stress, and starvation. According to some sources, several tens of thousands of Armenians, especially women, were forcibly Islamized in the province during the massacres.

It is impossible, unfortunately, to calculate the material losses of Armenians in the province, since a thousand houses, shops, churches and monasteries were all looted and many of them were set on fire.

After the massacres, the tendency for Armenians to migrate intensified.

Арпине Р. Баблумян

кандидат исторических наук

\section{АРМЯНСКОЕ НАСЕЛЕНИЕ ПРОВИНЦИИ ДИАРБЕКИР ЗАПАДНОЙ АРМЕНИИ В ГОДЫ ГАМИДОВСКИХ ПОГРОМОВ}

\section{PЕЗЮМЕ}

Ключевые слова: Западная Армения, Диарбекир, Тигранакерт, Амид, Балу, Северек, Аргана Маден, насильственная исламизация, истребления армян.

В провинции Диарбекир, как и в других провинциях Западной Армении, массовые истребления армян 1895 года были организованы властями и осуществлялись как рядовыми мусульманами, так и армией и полицией. В этой провинции, как и в других, были убиты десятки тысяч армян, также и сотни других христиан. Можно также предположить, что массовые убийства были направлены в первую очередь на армянское население, а другие христиане пострадали, поскольку во время массовых убийств иногда было трудно установить этническую принадлежность христиан, также было нелегко остановить курдов. Примечателен тот факт, что в некоторых населенных пунктах, где ассирийцы, католики и протестанты жили в большем количестве, нападавшие были в основном курды, а полиция и войска иногда принимали участие в их защите христиан.

Последствия истреблений не ограничивались количеством погибших во время истреблений: сотни, тысячи людей погибали и после истреблений из-за болезней, лишений, голода. Согласно некоторым источникам, во время резни в провинции было насильственно исламизировано несколько десятков тысяч армян, в особенности женщины.

К сожалению, невозможно подсчитать материальные потери, понесенные армянами в провинции, так как тысячи домов, лавок, церквей и монастырей были разграблены, многие из них были преданы огню. После погромов у армян усилилась тенденция к миграции. 


\section{REFERENCES}

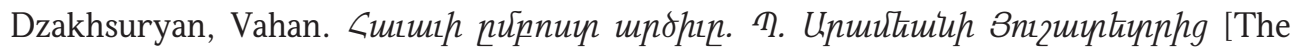
Rebel Eagle of Havav: From P. Aramyan's Notebook.]. New York, 1950;

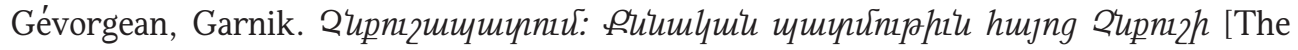
History of Ch'ngush. Critical History of the Armenian Ch'ngush]. Jerusalem, 1970;

Krayean, Mesrop. Amın [Balu]. Antilias, 1965;

Mkund, Tigran. Uußhumuһ mpámquiuqukn [The Echoes of Amid]. New Jersey: Dikran Spear, 1950;

Parsamean, Sargis. 3nızunămiu Rknuñlh [Monument to Jermuk]. Boston: Hamazgayin publ., 1969;

Ter-Yakovbean, Vaghinak. "Yh6ulumqnuluuu gnıgunnnıu SuGlyuhujuuunuhh» [Statistics of Turkish Armenia]. Ararat journal 50 no. 9 (1914): 808-814;

Uninta uuuuqhp. [Murch journal]. Tiflis, 1897;

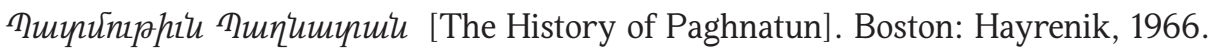

